\title{
DNA damage as a mechanism of neurodegeneration in ALS and a contributor to astrocyte toxicity
}

\author{
Jannigje Rachel Kok ${ }^{1}$ (D) Nelma M. Palminha ${ }^{2,3} \cdot$ Cleide Dos Santos Souza $^{1}$ (D) S Sherif F. El-Khamisy ${ }^{2,3,4} \mathbb{D}$. \\ Laura Ferraiuolo ${ }^{1,3}$
}

Received: 20 November 2020 / Revised: 27 April 2021 / Accepted: 5 June 2021 / Published online: 26 June 2021

(c) The Author(s) 2021

\begin{abstract}
Increasing evidence supports the involvement of DNA damage in several neurodegenerative diseases, including amyotrophic lateral sclerosis (ALS). Elevated levels of DNA damage are consistently observed in both sporadic and familial forms of ALS and may also play a role in Western Pacific ALS, which is thought to have an environmental cause. The cause of DNA damage in ALS remains unclear but likely differs between genetic subgroups. Repeat expansion in the C9ORF72 gene is the most common genetic cause of familial ALS and responsible for about $10 \%$ of sporadic cases. These genetic mutations are known to cause R-loops, thus increasing genomic instability and DNA damage, and generate dipeptide repeat proteins, which have been shown to lead to DNA damage and impairment of the DNA damage response. Similarly, several genes associated with ALS including TARDBP, FUS, NEK1, SQSTM1 and SETX are known to play a role in DNA repair and the DNA damage response, and thus may contribute to neuronal death via these pathways. Another consistent feature present in both sporadic and familial ALS is the ability of astrocytes to induce motor neuron death, although the factors causing this toxicity remain largely unknown. In this review, we summarise the evidence for DNA damage playing a causative or secondary role in the pathogenesis of ALS as well as discuss the possible mechanisms involved in different genetic subtypes with particular focus on the role of astrocytes initiating or perpetuating DNA damage in neurons.
\end{abstract}

Keywords Amyotrophic lateral sclerosis $\cdot$ Neurodegeneration $\cdot$ DNA damage $\cdot$ DNA damage response $\cdot$ Astrocytes

\section{Introduction}

\section{ALS and DNA damage}

Amyotrophic lateral sclerosis (ALS) was first described by Jean-Martin Charcot in the nineteenth century after he associated specific patterns of spinal cord white and grey matter damage with patients exhibiting muscle weakness and atrophy [1]. Death normally occurs within $2-3$ years of symptom onset, following weakness of the respiratory muscles leading to respiratory failure [2]. The only treatments currently available are riluzole and edaravone, which lead to a modest improvement in lifespan [3, 4]. The majority of ALS patients have no family history of the disease and are classed as sporadic ALS (sALS) patients [5], whereas approximately $5 \%$ have a family history of the disease due to inheritance of a mutation in an ALS associated gene and are classed as familial ALS (fALS) patients [6]. A third classification of ALS exists, often referred to as Western Pacific ALS, which occurs with unusually high incidence in a few regions 
including Guam and the Japanese Kii peninsula, leading to the suggestion that it had an environmental cause [7,8].

Studies of fALS patients have identified a number of genes which are causally associated with ALS (Table 1), the two most common of which are the chromosome 9 open reading frame $72(C 9 O R F 72)$ gene $[9,10]$, and the copper-zinc superoxide dismutase (SODI) gene [11]. Studies on fALS genes have suggested a number of possible mechanisms of motor neuron degeneration including excitotoxicity, oxidative stress, protein aggregation and defects in cell pathways such as autophagy, RNA metabolism, and the DNA damage response (DDR) [12]. The finding that a number of fALS genes play roles in the DDR is particularly striking as DNA damage has been established to be a feature of both sporadic and familial ALS since the 1990s [13, 14], before many of these genes were linked to ALS. DNA damage and deficiencies in the DDR thus may play a widespread role in ALS.

ALS is also considered to have a non-cell autonomous contribution to disease, as glia from ALS patients, including astrocytes, oligodendrocytes and microglia, exhibit a toxic phenotype not observed in healthy cells [15]. Of particular note, ALS astrocytes regardless of disease background, induce cell death in healthy motor neurons both via direct contact and through secreted factors [16], demonstrating non-cell autonomous mechanisms of motor neuron death. While the secreted factors that cause ALS toxicity remain largely unknown, there is growing evidence that proteins involved in DNA damage and DDR impairments, such as p62 and C9ORF72 dipeptide repeat proteins, could be secreted by ALS astrocytes [17, 18].

\section{DNA damage and response}

DNA damage is a common occurrence in cells, with each cell estimated to experience $10^{4}-10^{5}$ DNA lesions per day. If left unrepaired these lesions can lead to severe consequences, including cell death [38]. DNA damage can occur by chance during transcription or due to harmful genotoxic agents and can affect both nuclear and mitochondrial DNA [37]. Examples of DNA damage (Fig. 1) include oxidation or deamination of bases, base insertions or deletions or substitutions, and DNA double or single-stranded breaks (DSBs or

Table 1 Key Mendelian genes associated with ALS

\begin{tabular}{|c|c|c|c|c|}
\hline Gene & Full Name & Healthy Role & fALS Prevalence & Key Reference \\
\hline C9ORF72 & Chromosome 9 open reading frame 72 & Autophagy & $3-34 \%$ & {$[9,10]$} \\
\hline$S O D 1$ & Superoxide dismutase type-1 & Oxidative stress & $\mathbf{1 5}-\mathbf{3 0} \%$ & [11] \\
\hline$T A R D B P$ & $\begin{array}{l}\text { Transactive response DNA binding pro- } \\
\text { tein } 43 \mathrm{kDa}\end{array}$ & RNA metabolism, DDR & $1-4 \%$ & [19] \\
\hline FUS & Fused in sarcoma & RNA metabolism, DDR & $3-6 \%$ & {$[20,21]$} \\
\hline NEK1 & $\begin{array}{l}\text { Never-in-mitosis A related protein kinase } \\
\quad 1\end{array}$ & Cell cycle, DDR & $3 \%$ & {$[22]$} \\
\hline OPTN & Optineurin & Autophagy & $3 \%$ & {$[23]$} \\
\hline$\underset{p 62}{S Q S T M 1}$ or & Sequestosome 1 or p62 & Ubiquitination, autophagy, DDR & $2 \%$ & {$[24]$} \\
\hline$V C P$ & Valosin-containing protein & $\begin{array}{l}\text { Proteasome, vesicle trafficking, } \\
\text { autophagy, DDR }\end{array}$ & $1-2 \%$ & {$[25]$} \\
\hline$T B K 1$ & TANK-binding kinase 1 & Autophagy & $1 \%$ & [26] \\
\hline SETX & Senataxin & $\mathbf{R}$ loop resolution & $<1 \%$ & {$[27]$} \\
\hline$A L S 2$ & Alsin & Vesicle trafficking & $<1 \%$ & {$[28]$} \\
\hline CHCHD10 & $\begin{array}{l}\text { Coiled-coil-helix-coiled-coil-helix domain- } \\
\text { containing protein } 10\end{array}$ & Mitochondrial function & $<1 \%$ & [29] \\
\hline$C H M P 2 B$ & Charged multivesicular body protein $2 \mathrm{~B}$ & $\begin{array}{l}\text { Vesicle trafficking, autophagy, lysosomal } \\
\text { pathway }\end{array}$ & $<1 \%$ & {$[30]$} \\
\hline MATR3 & Matrin 3 & Transcription, RNA metabolism & $<1 \%$ & {$[31]$} \\
\hline PFN1 & Profilin 1 & Cytoskeleton, axon growth & $<1 \%$ & {$[32]$} \\
\hline$U B Q L N 2$ & Ubiquilin 2 & Proteasome, autophagy & $<1 \%$ & {$[33]$} \\
\hline$V A P B$ & $\begin{array}{l}\text { Vesicle-associated membrane protein-asso- } \\
\text { ciated protein } \mathrm{B} / \mathrm{C}\end{array}$ & Autophagy & $<1 \%$ & [34] \\
\hline
\end{tabular}

For more comprehensive review of ALS genetics, see [35]. Prevalence of $<1 \%$ indicates gene mutations only present in a few families or cohorts, making accurate prevalence measurements difficult. Bold rows indicate genes thought to be involved in the DNA damage response (DDR) and repair 


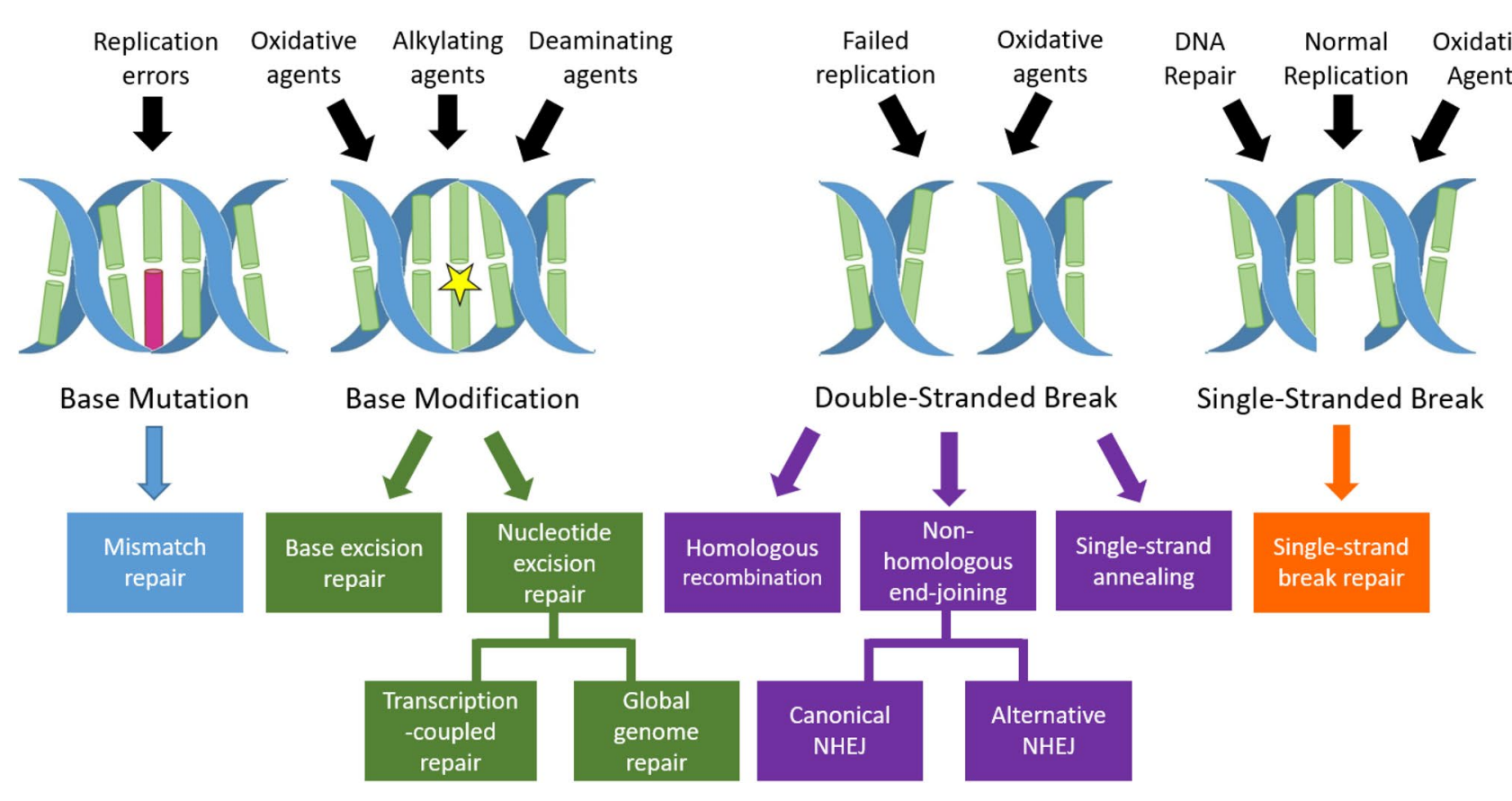

Fig. 1 DNA damage and related repair pathways. Various types of DNA damage exist which can be induced by genotoxic agents or can occur during normal cellular events. Several DNA repair pathways exist to repair specific types of DNA damage [36, 37]

SSBs) [36]. Oxidative DNA damage is measured by assaying for oxidation of DNA nucleosides, usually deoxyguanosine. Oxidised deoxyguanosine (OdG) can exist in two interconverting forms: 8-hydroxy-2-deoxyguanosine (8-OHdG) and 8-oxo-2-deoxyguanosine (8-oxodG) [39]. These names are often used interchangeably in ALS DNA damage studies and will both be referred to as OdG in this article.

\section{DNA damage response}

The DNA damage response (DDR) is a signal transduction pathway (Fig. 2) which exists to detect and respond to DNA damage. DNA damage is detected by sensors which bind the DNA ends, including the MRN complex, Ku70/80 heterodimer and RPA [36]. The DNA damage sensors activate master DNA repair phosphatidylinositol 3-kinase-related kinases (PIKKs), including ataxia telangiectasia mutated (ATM) and ATM and Rad3 related (ATR), which induce a phosphorylation cascade that activates effector proteins involved in pathways including cell cycle arrest, chromatin remodelling, DNA repair, and apoptosis [36]. Another key DNA repair kinase is DNA-PK, which is composed of a catalytic subunit (DNA-PKcs) and the Ku70/Ku80 heterodimer. DNA-PK is thought to regulate p53-mediated apoptosis following DNA damage and plays a critical role in non-homologous endjoining (NHEJ) DNA DSB repair by recruiting and phosphorylating NHEJ DNA repair proteins [40]. Two key phosphorylation targets of ATM, ATR and DNA-PK are histone
$\mathrm{H} 2 \mathrm{AX}$ and p53. Phosphorylated histone $\mathrm{H} 2 \mathrm{AX}(\gamma \mathrm{H} 2 \mathrm{AX})$ is thought to act as a docking site for DDR signalling and DNA repair, as several DDR components co-localise with $\gamma \mathrm{H} 2 \mathrm{AX}$ foci [38]. p53 is involved in activating DNA repair pathways, but if DNA damage is too extensive or cannot be repaired, then $\mathrm{p} 53$ promotes apoptosis by increasing the transcription of pro-apoptotic genes [41].

\section{DNA damage response and repair in neurons}

DNA damage and DNA repair deficiency have long been associated with neurodegeneration as mutations in DDR and DNA repair genes have been found to cause a number of neurodegenerative diseases, including ataxia telangiectasia, ataxia telangiectasia-like disorder, Nijmegen breakage syndrome, ataxia-oculomotor apraxia-1 and 2, ALS4 (caused by mutations in SETX, [27]), spinocerebellar ataxia with axonal neuropathy-1, and Cockayne syndrome [42]. DNA damage has also been implicated as playing a role in Alzheimer's disease, Huntington's disease and Parkinson's disease [42]. Notably, the majority of neurodegenerative diseases caused by DDR or DNA repair gene mutations affect cerebellar neurons specifically rather than motor neurons. Motor neurons can also be affected by DNA repair deficiencies as mice with reduced expression of Ercc1, a protein involved in nucleotide excision repair (NER), show age-dependent motor neuron degeneration and astrogliosis, similar to ALS [43].

Despite a clear association between DNA damage and neurodegeneration, the DDR and DNA repair have not been 


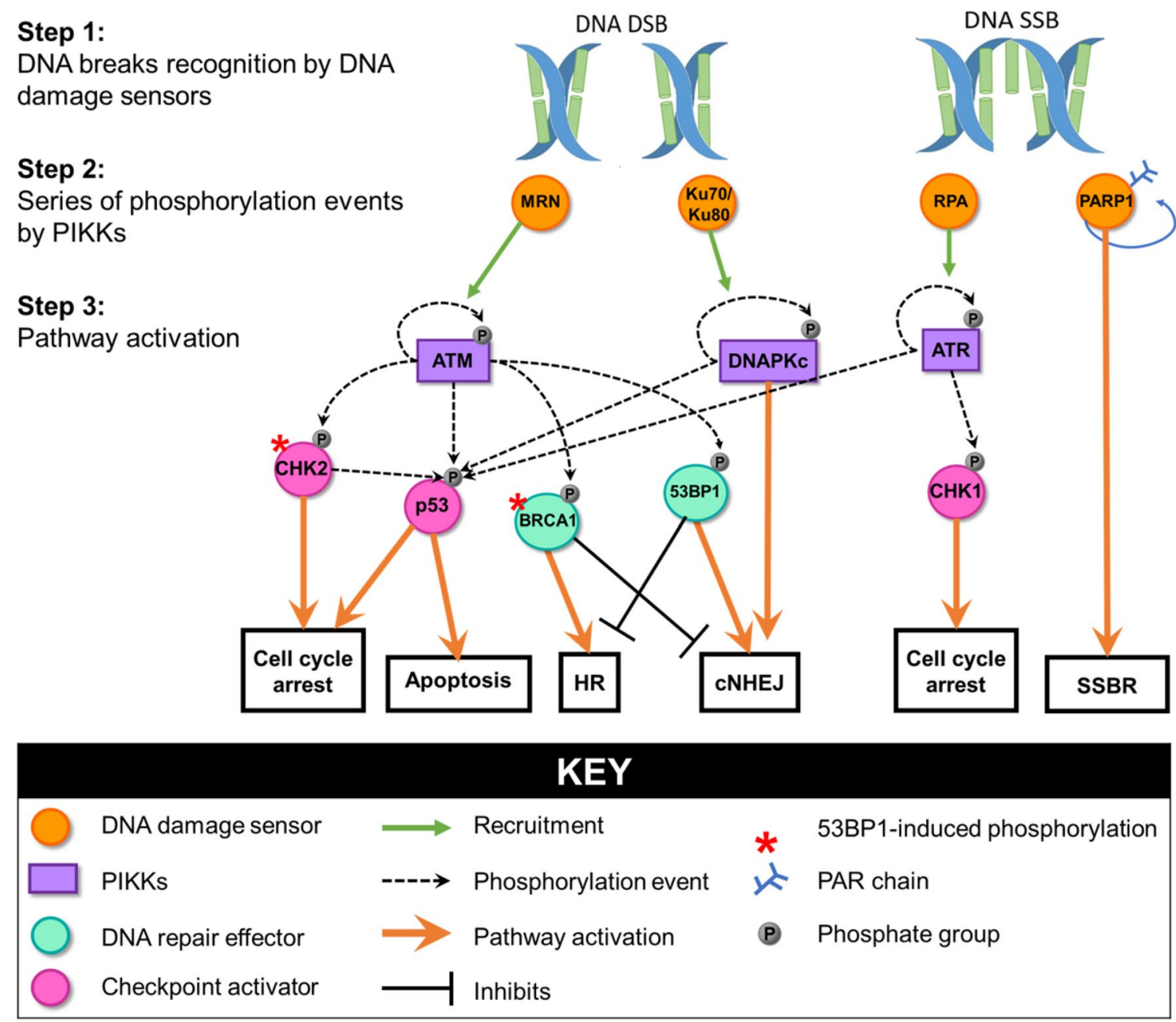

Fig. 2 Schematic showing simplified DNA damage response. DNA damage is detected by factors which activate master DNA repair kinases such as ATM and ATR. The repair kinases phosphorylate

extensively studied in neurons or compared between different neuron populations, and it remains unclear whether specific neuron types like motor neurons are more vulnerable to DNA damage or DNA repair deficiencies. DNA repair kinetics have been compared between astrocytes and neurons, and it was shown that both astrocytes and neurons are dependent on TDP1 for DNA SSB repair [44]. One likely explanation for general neuron vulnerability to DNA damage is their high metabolic activity and reliance on oxidative phosphorylation over glycolysis as their main source of energy, which leads to increased generation of reactive oxygen species and consequently leads to increased oxidative DNA damage [42]. A factor that could compound this effect is the mitotic status of neurons as it has previously been suggested that post-mitotic cells are more likely to accumulate DNA damage than mitotic cells. For example, it has been shown that post-mitotic parenchymal liver cells exhibit an downstream targets to lead to cell cycle arrest, apoptosis and DNA repair. Notably, several actions including p53 phosphorylation are redundant and performed by multiple kinases $[36,38]$

age-related increase in alkali-labile sites that is not observed in mitotically active non-parenchymal liver cells [45].

DNA repair mechanisms differ between mitotic and post-mitotic cells. Some DNA repair mechanisms, specifically homologous recombination (HR) and mismatch repair (MMR), are dependent on the cell cycle and thus may play more of a role in dividing cells compared to postmitotic cells [46]. Studies have also shown that base excision repair (BER) and nucleotide excision repair (NER), which occur independent of the cell cycle, are affected by mitotic status. Post-mitotic neurons have reduced activity of BER and NER global genome repair (but not transcription-coupled repair), and reduced levels of some BER proteins compared to the mitotic cells they were differentiated from $[47,48]$. DNA repair may, therefore, be less efficient in neuronal cells and contribute to neuron vulnerability to DNA damage. Notably, DNA breaks in neurons are not always detrimental. Indeed, neuronal activity has been 
shown to induce DNA DSB generation by topoisomerase II $\beta$ for the purpose of activating transcription of neuronal activity early response genes, which play roles in synaptic plasticity [49]. These activity-induced DSBs are rapidly repaired through the canonical non-homologous endjoining (c-NHEJ) DNA repair pathway [49], indicating neurons are capable of repairing targeted DNA damage.

DNA damage response and DNA repair have been examined as potential therapeutic targets for neurodegeneration. As such, it is of importance to generate models to test putative molecules. For example, knockout of $t d p 1$ in zebrafish identified apex 2 and ercc 4 as putative molecules which compensated for $t d p 1$ loss [50]. Enforcing DNA repair has been shown to improve motor neuron survival following injury. In an in vivo mouse study, expression of human BER proteins, OGG1 or APEX1, attenuated phosphorylated p53 expression in lesioned neurons and reduced motor neuron apoptosis following axotomy, with a greater effect seen with APEX1 expression [51]. APEX1 overexpression has also been shown to improve cell viability following oxidative stress induction in hippocampal neurons or sensory neurons, while APEX1 knockdown reduced cell viability [52]. Surprisingly, suppressing the DDR has also been shown to be neuroprotective as ATM inhibition reduces DNA damage-mediated apoptosis in genotoxin-treated neurons [53]. Similarly, PARP inhibition has been shown to be neuroprotective in models of Huntington's disease [54] and stroke [55]. It may be that inhibiting DDR signalling prevents p53 phosphorylation and consequently prevents p53-mediated apoptosis. Thus, suppressing the DDR or enforcing DNA repair could be a therapeutic strategy for neurodegenerative disease.

\section{Specific ALS subtypes and DNA damage}

\section{C9ORF72}

A hexanucleotide (GGGGCC) repeat expansion in the first intron of the chromosome 9 open reading frame 72 (C9ORF72) gene is the most common cause of fALS in the West $[9,10]$. Several studies have identified increased protein expression and staining for $\gamma \mathrm{H} 2 \mathrm{AX}$ in C9ORF72-ALS patient post-mortem spinal cord tissue and iPSC-derived motor neurons, suggesting DNA damage is increased in C9ORF72-ALS [56-60]. Products of the C9ORF72 repeat expansion have been suggested as a primary cause of C9ORF72-ALS. The repeat expansion is transcribed into sense and antisense repeat-expansion RNAs (RREs), which can undergo repeat-associated non-ATG (RAN) translation to generate five dipeptide repeat proteins (DPRs): poly(GA),

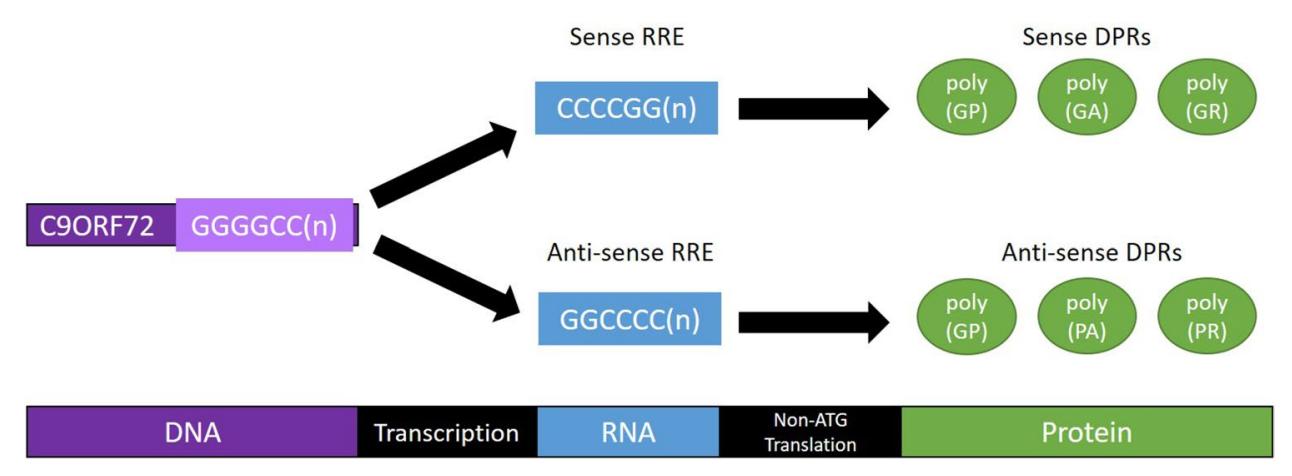

Fig. 3 Transcription and translation of the C9ORF72 repeat expansion. The C9ORF72 repeat expansion is transcribed in both the sense and anti-sense directions to produce two RNA repeat expansion transcripts. Each transcript can be processed by non-ATG translation to produce a total of five different types of dipeptide repeat protein. The poly(GP) DPR is produced by translation of both the sense and antisense transcripts [61]. RRE $=$ RNA repeat expansion, $D P R=$ dipeptide repeat protein
Table 2 Summary of DPR properties

\begin{tabular}{lllll}
\hline DPR Species & Transcript & $\begin{array}{l}\text { Toxic to Motor } \\
\text { Neurons? }\end{array}$ & Induces DNA damage? & References \\
\hline Poly(GA) & Sense & Yes & Yes $_{1} / \mathrm{No}_{2}$ & {$[56,59,62]$} \\
Poly(GR) & Sense & Yes & Yes & {$[56,58,62,63]$} \\
Poly(GP) & Sense and anti-sense & No & Not reported & \\
Poly(PA) & Anti-sense & No & Not reported & \\
Poly(PR) & Anti-sense & Yes & Yes & {$[58,62]$} \\
\hline
\end{tabular}

${ }_{1}[59,62]$ showed transfecting cells with poly $(\mathrm{GA})$ led to increased DNA damage, but ${ }_{2}[56]$ did not find the same effect. DPR toxicity or non-toxicity shown in references [64-66] 
poly(GR), poly(GP), poly(PR) and poly(PA) [61] (Fig. 3). Viral expression of C9ORF72-ALS RREs or certain DPRs (Table 2) in neuronal cells is sufficient to induce DNA strand breaks and increased $\gamma \mathrm{H} 2 \mathrm{AX}$ levels $[56,58,62]$, suggesting DNA damage in C9ORF72-ALS is caused by RREs or DPRs.

Increased DNA damage in C9ORF72-ALS could be caused by changes in genotoxic agents, such as reactive oxygen species (ROS) [56], or due to increased R-loop formation [59]. ROS are a natural source of DNA damage and have been implicated as the cause of DNA damage in C9ORF72-ALS. ROS production has been shown to increase at the same time as DNA damage in C9ORF72-ALS iPSCderived motor neurons and poly(GR) transfected cells, in an age-dependent manner [56]. Additionally, DNA damage could be partly rescued by depleting ROS with an antioxidant treatment [56]. A possible cause of increased ROS could be mitochondrial dysfunction, which is known to be induced by poly(GR) expression [63]. Similarly, R-loops, which are naturally occurring RNA:DNA hybrids that can induce DNA strand breaks, are increased in C9ORF72ALS post-mortem spinal cord tissue and poly(GA) DPR transfected cells [59]. Both DNA damage and cell death in poly(GA) transfected cells could be partly rescued by overexpressing senataxin, a gene involved in R-loop resolution [59]. Thus, increased ROS and/or R-loops have been shown to contribute to increased DNA damage in C9ORF72-ALS.

Another consequence of the repeat expansion in C9ORF72-ALS is the accumulation of protein-linked DNA breaks caused by trapped TOP1 cleavage complexes (TOP1cc), as observed in cells expressing RREs and DPRs $[59,67]$. Of relevance, these mechanisms may also feed into each other, as ROS are known to cause both R-loops and TOP1cc [68]. In turn, ROS-dependent accumulation of co-transcriptional R-loops and TOP1cc-dependent SSBs in opposite neighboring DNA strands induces DSBs during transcription [68-71], thus exacerbating a cellular insult that can result in neuronal death.

DDR signalling and DNA repair have been shown to be dysfunctional in C9ORF72-ALS and could contribute to increased DNA damage. Repeat expansions in general have been suggested to hinder DNA repair [72]. Furthermore, chromatin compaction and expression of factors that promote this process are increased in C9ORF72-ALS spinal cord tissue and poly(GA) transfected cells, which could hinder access to DNA repair factors. Accordingly, inducing chromatin relaxation reduced $\gamma \mathrm{H} 2 \mathrm{AX}$ levels and cell death in poly(GA) transfected cells [59].

Interestingly, while poly(GA), poly(GR) and poly(PR) all cause DNA damage [56, 59, 62, 63], they appear to have different effects on the DDR and DNA repair (Table 3 ). Poly(GA), in fact, has been shown to aggregate and sequester pATM in the cytoplasm, preventing its recruitment to DNA damage sites [62]. This subsequently leads to reduced pATM, 53BP1, and phosphorylated p53 expression in poly(GA) transfected cells, with the effect persisting following DNA damage induction $[59,62]$. The significance of this effect remains unclear, however, as C9ORF72ALS motor neurons and cells transfected with poly(GR) or poly(PR) DPRs show an expected increase in pATM, 53BP1 and phosphorylated p53 expression, corresponding with the observed DNA damage [58, 62, 73]. Importantly, p53 appears to play a key role in C9ORF72-ALS and DPRinduced toxicity as p53 knockout or knockdown has been shown to extend the lifespan of a mouse model expressing poly(PR), and protect against neurodegeneration in Drosophila models expressing the C9ORF72 repeat expansion [74]. Strikingly, p53 knockout also reduces DNA damage $(\gamma \mathrm{H} 2 \mathrm{AX}$ levels and comet tail measurements) in poly(PR) transduced cells and C9ORF72-ALS iPSC-derived motor neurons, indicating p53 action may be occurring upstream of DNA damage rather than downstream [74].

The ATM signalling pathway is thought to be primarily involved in homologous recombination (HR) DNA repair [76]. While DPRs have been shown to reduce the efficiency of certain DNA repair pathways (Table 3), they have not been shown to affect HR DNA repair [60]. Instead, DPRs appear to affect canonical and alternative non-homologous end-joining (c-NHEJ and alt-NHEJ) and single-strand annealing (SSA) DNA repair [60]. Most notably, efficiency of c-NHEJ is reduced following transfection with any of the three key DNA damage-inducing DPRs: poly(GA),

Table 3 Effects of DPRs on DDR and DNA repair

\begin{tabular}{|c|c|c|c|c|}
\hline DPR & $\begin{array}{l}\text { DDR signalling }[58,59,62,73 \text {, } \\
74]\end{array}$ & DNA repair [60] & Binds DDR factors? & Other effects in cells \\
\hline Poly(GA) & $\begin{array}{l}\text { Reduced pATM; reduced 53BP1; } \\
\text { reduced p53 }\end{array}$ & Reduced c-NHEJ; reduced SSA & pATM [62]; HR23B [75] & $\begin{array}{l}\text { Increased R-loops [59]; increased } \\
\text { chromatin compaction } \\
\text { (H3K9me3, HDAC4) [59] }\end{array}$ \\
\hline Poly(GR) & $\begin{array}{l}\text { Increased pATM; increased p53; } \\
\text { increased Ku } 80\end{array}$ & Reduced c-NHEJ & NPM1 $[58,60]$ & $\begin{array}{l}\text { Increased ROS [56]; mitochondrial } \\
\text { defects [63] }\end{array}$ \\
\hline Poly(PR) & Increased pATM; increased p53 & $\begin{array}{l}\text { Reduced c-NHEJ; reduced } \\
\text { SSA; reduced alt-NHEJ }\end{array}$ & NPM1 $[58,60]$ & Not reported \\
\hline
\end{tabular}


poly(GR) and poly(PR) [60]. C-NHEJ is mediated through the Ku70/Ku80 DDR pathway [77], which has been shown to be affected in C9ORF72-ALS. Ku70, Ku80 and DNAPKcs expression were shown to be increased in C9ORF72ALS iPSC-derived motor neurons and poly(GR)-expressing Drosophila [73]. Accordingly, knockdown of Ku80 or ATM reduced cell death in this fly model [73]. It was suggested that Ku80 overexpression may lead to NHEJ overactivation [73], which is perhaps unexpected considering the reduced c-NHEJ efficiency observed in the other study [60]. However, it has previously been shown that overexpression of $\mathrm{Ku} 70$ and Ku 80 in rat fibroblasts leads to reduced DNA-PK activity and increased residual DNA damage twenty-four hours after irradiation [78], suggestive of a NHEJ impairment. Thus increased Ku70/Ku80 signalling could be another mechanism inducing cell death in C9ORF72-ALS.

Reduced efficiency of DNA repair could also be mediated through NPM1, a DNA repair factor associated with BER, NHEJ and SSA, as poly(GR) and poly(PR) directly bind and potentially impair NPM1 $[58,60]$. Poly(GA) has also been observed to form cytoplasmic inclusions with HR23B, a protein involved in nucleotide excision repair (NER), although NER efficiency was reported to be unaffected [75]. Thus, increased DNA damage in C9ORF72-ALS could arise from deficiencies in DNA repair or the DDR, as well as potential increases in genotoxic agents.

\section{SOD1}

Mutations in the copper-zinc superoxide dismutase (SOD1) gene were the first identified the cause of fALS [11] and remain the second most common cause of fALS, being responsible for approximately $15 \%$ of all fALS cases and $1 \%$ of sALS cases [79]. SOD1 is an antioxidant enzyme which protects cells against ROS, so SODI mutations were thought to cause motor neuron death through increased oxidative damage [80]. Limited studies of human SOD1-ALS patients have shown increased levels of OdG in the CSF [81, 82], but reduced levels in the motor cortex compared to controls [13]. By contrast, with the exception of one study finding no change in DNA damage [83], studies of SOD $1^{\mathrm{G} 93 \mathrm{~A}}$ mouse models have consistently shown increased OdG or $\gamma \mathrm{H} 2 \mathrm{AX}$ levels, specifically in spinal cord, frontal cortex and striatum, but not the cerebellum which is spared of neurodegeneration [84-87]. Two studies showed DNA damage occurred pre-symptomatically in SOD $1^{\mathrm{G} 93 \mathrm{~A}}$ mice $[85,86]$, however, another only observed DNA damage after symptom onset [84]. These results could suggest DNA damage is a cause of motor neuron degeneration and interestingly interventions such as docosahexaenoic acid (DHA) enriched diet which improve SOD1-ALS mouse survival have also been shown to reduce DNA damage [88].

Loss of SOD1 function could be a mechanism through which SOD1 mutations lead to DNA damage. Wild-type SOD1 has been suggested to be protective against DNA damage as two studies have shown cells transfected with SOD ${ }^{\text {WT }}$ exhibit less DNA damage and oxidative stress than untransfected cells before and after $\mathrm{H}_{2} \mathrm{O}_{2}$ treatment $[89,90]$, although another study failed to replicate this finding [91]. We thus might expect that SOD1 mutations would lead to the loss of this protective effect. Accordingly, expressing $\mathrm{SOD}^{\mathrm{A} 4 \mathrm{~V}}, \mathrm{SOD} 1^{\mathrm{L} 38 \mathrm{~V}}$ or $\mathrm{SOD} 1^{\mathrm{G} 93 \mathrm{C}}$ led to similar DNA damage levels as untransfected cells but higher levels than cells expressing SOD $1^{\mathrm{WT}}$, whereas transfection with $\mathrm{SOD} 1^{\mathrm{G} 93 \mathrm{~A}}$ or $\mathrm{SOD} 1^{\mathrm{H} 46 \mathrm{R}}$ led to increased DNA damage compared to both untransfected and SOD1 ${ }^{\mathrm{WT}}$, suggesting an additional gain of function effect for these mutations [89, 91-93].

A likely candidate for the protective effect of SOD $1^{\text {WT }}$ against DNA damage would be its dismutase ROS scavenging activity. It would be expected that SOD1 mutations that lead to increased DNA damage would affect the dismutase activity. This is, however, not the case. Several studies have shown that not all SOD1 mutations lead to loss of SOD1 ROS scavenging activity [94, 95]. Some mutations only mildly decrease SOD1 activity and others, including the SOD $1^{\mathrm{G} 37 \mathrm{R}}$ mutation, lead to increased activity $[94,95]$. Indeed, SOD $1^{\mathrm{A} 4 \mathrm{~V}}$, SOD $1^{\mathrm{G} 93 \mathrm{~A}}$ and $\mathrm{SOD} 1^{\mathrm{L} 38 \mathrm{~V}}$ exhibit dismutase activity levels similar to SOD ${ }^{\mathrm{WT}}$ [95], indicating that if there is loss of a protective function of SOD $1{ }^{\mathrm{WT}}$ function in these lines, it is not the dismutase function. On the other hand, the SOD $1^{\mathrm{H} 46 \mathrm{R}}$ mutation has been reported to lead to reduced dismutase activity due to severe metal deficiency [95], and while the G93A mutation is thought not to affect dismutase activity $[95,96]$ it does lead to increased peroxidase activity and a resulting increase in hydroxyl radical production [96]. Thus, changes in SOD1 dismutase or peroxidase activity and subsequent increases in ROS could be a mechanism through which DNA damage is increased in SOD1-ALS but is likely not the only mechanism.

Another mechanism through which wild-type SOD1 could exert a protective effect is through an as yet uncharacterised role in the DDR. SOD $1^{\mathrm{WT}}$ has been shown to associate with nuclear chromatin and this association is increased in SOD1 ${ }^{\mathrm{G} 93 \mathrm{~A}}$ transfected cells [91]. However, another study showed that expressing SOD $1^{\mathrm{G} 93 \mathrm{~A}}$ could cause SOD ${ }^{\mathrm{WT}}$ to become sequestered in the cytoplasm. Inducing nuclear import of SOD1 in these cells notably improved cell survival [87], suggesting a protective role for SOD $1^{\mathrm{WT}}$ in the nucleus.

In addition to potentially impairing the role of wild-type SOD1 in the DDR, SOD1 mutations have been shown to affect other DDR processes. Expression of Spy 1, a protein that inhibits apoptosis following DNA damage, is reduced in SOD $1^{\mathrm{G} 93 \mathrm{~A}}$ transfected cells and $\mathrm{SOD} 1^{\mathrm{G} 93 \mathrm{~A}}$ mouse spinal 
cord. Accordingly, overexpressing Spy 1 reduced DDR activation and cell death [92]. Reduction in Spy1 thus could sensitise cells to DNA damage and push the balance towards DNA damage rather than DNA repair. Potentially compounding this effect is the finding that expression of wild-type p53-induced phosphatase 1 (Wip1), a protein which dephosphorylates several DDR signalling proteins thus terminating the DDR, is also reduced in SOD1-ALS mice and SOD1-ALS cell models. Like with Spy1, overexpression of Wip1 improved cell viability [97]. Inability to terminate the DDR could lead to persistent activation and subsequently drive cells towards apoptosis.

The more classical DDR factors may also be involved in SOD1-ALS DNA damage. In accordance with the observed damage, DDR activation is increased in cells expressing SOD $1^{\mathrm{G} 93 \mathrm{~A}}$ as they exhibit increased $\mathrm{p} 53$ activity [91], and increased expression of pATM, pATR, pChk1 and p53 [87, 92]. However, it has been shown that several DDR and DNA repair components, including p53, FUS, HDAC1 and APEX1, fail to enter the nucleus or are mislocalised to the cytoplasm in cells expressing SOD $1^{\text {G93A }}$ [87]. This was not true for all DNA repair proteins as XRCC1, OGG1 and PARP1 showed normal localisation in SOD $1^{\mathrm{G} 93 \mathrm{~A}}$-expressing cells [87], and OGG1 has also been shown to have normal nuclear localisation in hSOD1 ${ }^{\mathrm{G} 93 \mathrm{~A}}$ transgenic mice [98]. Cytoplasmic restriction of DNA repair proteins would likely render them functionally inactive and potentially prevent DNA repair processes [87], however, it should be noted that several other studies have failed to observe mislocalisation of DNA repair proteins. Increased nuclear p53 immunoreactivity has been observed in spinal motor neurons in SOD $1^{\mathrm{G} 86 \mathrm{R}}$ mice [99]. Similarly, APEX1 is upregulated and enriched in the nuclei of ALS patient motor neurons [100], however, the majority of these patients were classed as sporadic so it is unclear if this also applies to SOD1-ALS patients. One study in SOD $1{ }^{\mathrm{hG} 93 \mathrm{~A}}$ mice found that expression of APEX1 was reduced in spinal motor neurons pre-symptomatically, indicating that a deficiency in DNA repair precedes motor neuron degeneration [101]. SOD $1^{\mathrm{G} 93 \mathrm{~A}}$ expression in cells deficient in the DDR protein aprataxin has been shown to sensitise cells to oxidative stress, exacerbate DNA repair deficiencies and increase levels of heterochromatin [102]. On the other hand, DNA repair has been suggested to be unaffected in SOD1-ALS iPSC-derived motor neurons as these motor neurons exhibit similar $\gamma \mathrm{H} 2 \mathrm{AX}$ kinetics to control motor neurons over time following DNA damage induction [103]. Notably, this shows overall DNA repair kinetics, and it remains unknown whether there are any deficits in specific DNA repair pathways, such as NHEJ, which are potentially compensated for. Thus, changes in expression or localisation of DDR factors may affect DNA repair and play a role in motor neuron degeneration in SODI-ALS.

\section{FUS}

Fused in sarcoma (FUS) is an RNA binding protein involved in the DDR, DNA repair and RNA processing, transcription and translation [104], which was also found to be a fALS gene [21]. DNA damage, measured by $\gamma \mathrm{H} 2 \mathrm{AX}$ or DNA strand breaks, is increased in FUSALS post-mortem motor cortex and spinal cord [105, 106], FUS-ALS iPSC-derived neural progenitor cells and motor neurons [106, 107], and FUS ${ }^{\mathrm{R} 521 \mathrm{C}}$ mice [108]. Given the role of FUS in DDR signalling and DNA repair, it seems likely that DNA damage in FUS-ALS is caused by FUS mutations affecting these processes.

FUS has been shown to be an early DDR signalling player, being recruited to DNA DSBs by PARP1 [105, 109-111]. The presence of FUS at chromatin is sufficient to induce $\gamma \mathrm{H} 2 \mathrm{AX}$ foci formation and may recruit other factors as FUS knockdown leads to reduced pATM retention at DNA DSBs [105]. FUS-ALS iPSCs exhibit a greater increase in $\gamma \mathrm{H} 2 \mathrm{AX}$ following irradiation than control iPSCs, indicating an increased sensitivity to DNA damage [107]. FUS-ALS mutations do not affect FUS accumulation at DNA DSBs, instead they affect recruitment of factors, as the presence of pATM and HDAC1 at DNA DSBs was reduced in cells expressing mutant FUS [105]. Another characteristic of mutant FUS is its propensity for cytosolic mislocalisation [107]. Motor neurons expressing mutant FUS were shown to form cytoplasmic FUS-bearing stress granules. The severity of the mutation was also shown to be associated with greater amounts of mislocalised FUS and with earlier disease onsets [107]. Whether FUS mislocalisation to the cytoplasm influences early DDR signalling is unknown. Interestingly, HDAC inhibitors, which reduce mutant FUS mislocalisation to the cytoplasm, have been shown to improve recruitment of FUS ${ }^{\mathrm{P} 525 \mathrm{~L}}$ to DNA damage sites, potentially preserving DDR signalling and DNA repair and thus suggesting FUS mislocalisation impacts DNA repair [112].

The role of FUS in later DDR signalling events is contested. Some studies have suggested FUS is not necessary for signalling downstream of ATM, as FUS knockdown does not affect levels of phosphorylated 53BP1, phosphorylated Chk2 [109], or $\gamma \mathrm{H} 2 \mathrm{AX}$ [110]. However, another study showed ATM signalling was defective in FUSdepleted neurons as following genotoxin treatment there was increased DNA DSBs, but reduced levels of $\gamma \mathrm{H} 2 \mathrm{AX}$, 53BP1 foci, and phosphorylated Chk2 [105]. The effect of FUS-ALS mutations on the expression of these DDR components has not yet been investigated, but this may be 
another mechanism through which FUS-ALS mutations could lead to increased DNA damage.

As well as the DDR, FUS is also involved in multiple DNA repair processes. FUS knockdown reduces the efficiency of HR and NHEJ $[105,109]$. Thus, we might expect FUS-ALS mutations to affect these DNA repair processes. Cells expressing ALS-associated mutant FUS exhibited reduced HR efficiency, with the effect dependent on the mutation. Some FUS mutants but not others additionally showed reduced NHEJ efficiency [105]. Reduced DNA repair efficiency is likely due to changes in the expression of DNA repair factors. Motor neurons carrying FUS ${ }^{\mathrm{P} 525 \mathrm{~L}}$ mutations show reduced protein levels of BRCA1, DNA ligase IV, RAD23B and MSH2; which is also observed in FUS-depleted cells [113]. DNA damage in FUS-ALS is likely to arise from loss of function effects on DNA repair.

\section{TDP-43}

The transactive response DNA binding protein $43 \mathrm{kDa}$ (TDP-43) was first associated with ALS as a pathological marker. In sALS, C9ORF72-ALS and many other fALS variants (but not SOD1-ALS), TDP-43 is mislocalised from the nucleus to the cytoplasm, and can be found in ubiquitinpositive inclusions $[114,115]$. It was only later that mutations in the TDP-43 gene, TARDBP, were found to cause a subset of ALS cases [19]. Therefore, when considering the potential role of TDP-43 in DNA damage, it is likely to apply to not only TARDBP-ALS cases but potentially sALS and fALS as well. An initial study of TARDBP-ALS iPSCderived motor neurons (carrying S393L and G294V mutations) showed reduced survival but no change in $\gamma \mathrm{H} 2 \mathrm{AX}$, suggesting DNA damage was not a feature of TARDBP-ALS [116]. However, more recent studies have shown increased $\gamma \mathrm{H} 2 \mathrm{AX}$ in the spinal cord of a TARDBP-ALS patient carrying the Q331K mutation [117] and in fibroblasts from a TARDBP-ALS patient carrying the M337V mutation [118]. Additionally, $\gamma \mathrm{H} 2 \mathrm{AX}$ has also been shown to be increased in cortical neurons of a mouse model of TDP-43 mislocalisation [118]. It is possible that increased DNA damage in TARDBP-ALS is mutation dependent, however, there is considerable evidence suggesting the involvement of TDP-43 in DNA damage response and repair that could be affected by TARDBP mutations.

TDP-43 was shown to play a role in DDR signalling by associating with several DDR proteins [119, 120]. Following DNA damage induction by transcriptional arrest or DNA DSB generation, TDP-43 colocalises with $\gamma \mathrm{H} 2 \mathrm{AX}$ and FUS in the nucleus [111, 118], and can directly bind DNA DSBs [119]. Additionally, TDP-43 interacts with components of the NHEJ protein complex, with the association increasing following DNA damage induction [119]. TDP-43 further aids NHEJ-mediated DSB repair by promoting the recruitment of XRCC4-Lig4 complex to the chromatin [119]. Interestingly, TDP-43 containing ALS-linked mutations, including the $\mathrm{A} 315 \mathrm{~T}$ or $\mathrm{Q} 331 \mathrm{~K}$ mutations, is still recruited to DNA damage sites but shows reduced interaction compared to wild-type TDP-43 [118]. Accordingly, overexpressing wildtype TDP-43 led to reduced DNA damage following etoposide treatment in NSC-34 cells, with the protective effect lost when TDP-43 carrying the Q331K or A315T mutations was expressed instead [118]. TDP-43 mutations thus may lead to impairment of the function of TDP-43 in DDR signalling or DNA repair.

In fact,TDP-43 knockdown has been shown to lead to increased DNA strand breaks [111, 119] but no increase in $\gamma \mathrm{H} 2 \mathrm{AX}$ [118]. One study suggested this only occurred in response to the transcriptional arrest, and DNA damage could be rescued by overexpressing a protein that resolves R-loops, suggesting TDP-43 may be involved in the prevention or repair of R-loop associated DNA damage [111]. It thus might be expected that R-loops would be increased in TARDBP-ALS, however, this has not yet been investigated. Long-term TDP-43 depletion has been shown to lead to a long-term increase in PATM, indicating sustained DDR activation, and eventually cell death [119]. In addition,TDP-43 depletion leads to reduced association of NHEJ DNA repair proteins XRCC4, Lig4 and XLF with $\gamma \mathrm{H} 2 \mathrm{AX}$ and 53BP1 [119]. This results in an overall reduction in NHEJ activation following induction of DNA DSBs in TDP-43 depleted cells [119]. Similar results were seen in cells expressing TDP-43 carrying the Q331K or A315T mutations and in fibroblasts from a TARDBP-ALS patient carrying the M337V mutation, with a specific impairment in the c-NHEJ pathway observed rather than the alt-NHEJ pathway [118]. This way, TDP-43 mutations or mislocalisation could lead to increased DNA damage through reduced DNA repair or impaired DDR signalling.

\section{NEK1}

Never-in-mitosis A related protein kinase 1 (NEK1), another gene associated with the DDR [121], is also a fALS gene [22]. As NEK1 was only recently associated with ALS, there is only one associated DNA damage study. NEKIALS iPSC-derived motor neurons showed increased $\gamma \mathrm{H} 2 \mathrm{AX}$ compared to controls, indicating DNA damage is a feature of NEK1-ALS [57]. Like with FUS, it is likely that DNA damage in NEK1-ALS is due to the haploinsufficiency of NEK1 affecting its involvement in DDR signalling and DNA repair. NEK1 protein expression is reduced by $50 \%$ in NEK1-ALS patient cells [57], and NEK1 knockdown has also been shown to lead to increased morphological signs of DNA damage [122] and reduced cell survival following 
genotoxic treatment $[121,123]$. Thus, NEK1 depletion leads to increased DNA damage and increased sensitivity of cells to DNA damage.

NEK1 may play a role in DDR signalling downstream of ATM/ATR. At baseline and following DNA damage induction, NEK1-ALS iPSC-derived motor neurons do not exhibit changes in pATM levels but do exhibit elevated pBRCA1 and slightly reduced p53 [57]. This could mean NEK1-ALS motor neurons are more 'primed' to respond to DNA damage. NEK1 is also involved in cell cycle arrest. Following DNA damage induction, both NEK1-ALS motor neurons and NEK1 knockdown cells exhibit reduced phosphorylation of Chk1 and Chk2 which would potentially prevent cell cycle arrest $[57,123,124]$. Cell cycle re-entry has been suggested to be necessary for DNA repair in neurons [125], thus cell cycle impairment may lead to DNA damage accumulation in NEK1-ALS. Interestingly, unlike NEK1-ALS motor neurons, actively dividing NEK1-ALS iPSCs do not exhibit increased DNA damage compared to controls [57]. Thus, the role of NEK1 may be more important in post-mitotic cells, meaning motor neurons would be more vulnerable to mutations than dividing cells.

NEK1 may also play a key role in DNA repair. Following DNA damage induction, NEKI-ALS motor neurons and NEK1 knockdown cells exhibit accumulation of $\gamma \mathrm{H} 2 \mathrm{AX}$ over time, indicating a lack of DNA repair [57, 123, 124]. NEK1 has been shown to phosphorylate and activate Rad54, a protein involved in HR DNA DSB repair [126]. Thus, it seems likely that increased DNA damage in NEK1-ALS could arise due to deficiencies in HR DNA repair, but this has not yet been investigated.

\section{Sporadic ALS}

DNA damage is not unique to fALS, in fact the first studies reporting DNA damage in ALS were performed in sALS patient post-mortem tissue. They found increased OdG levels in sALS spinal cord and motor cortex, but not in the parietal cortex or cerebellum, suggesting DNA damage was a feature in sALS and was specific to regions where motor neurons degenerate $[13,14,103]$. Without a genetic link to investigate, it has been more difficult to elucidate the mechanisms of DNA damage in sALS motor neurons. Motor neurons are post-mitotic and not replaced throughout life, so exposure to genotoxic agents and/or chance accumulation of DNA damage over time could lead to motor neuron degeneration in sALS. ALS incidence and DNA damage levels are known to increase with age [81, 127], while DNA repair efficiency decreases [128]. Additionally, several suggested risk factors for developing ALS, including smoking and exposure to chemicals, pesticides and metals, could be sources of genotoxic agents [129].
Deficiencies in DNA repair in ALS could be due to changes in the expression of proteins involved in DDR. Consistent with this hypothesis, in sALS motor neurons PARP expression is reduced [130], while phosphorylated c-Abl and BRCA1 expression is increased [103]. In sALS post-mortem motor cortex, APEX1 expression was reported to be reduced in one study [131], but another study showed nuclear enrichment and increased APEX1 activity [100]. Furthermore, methylation of DNA repair genes including OGG1, which is involved in oxidative DNA damage repair, is reduced in sALS motor cortex [103]. Notably mitotic cells, such as bone marrow mesenchymal stem cells and blood cells do not exhibit increase in DNA damage in sALS [132, 133], possibly because of their ability to repair DNA damage during the cell cycle or because of their turnover. This was found not to be true for sALS dermic fibroblasts, which exhibit increased DNA damage and reduced DNA repair, but also have a reduced proliferation rate compared to control fibroblasts, which could account for the increased DNA damage [134]. Mitotic status therefore may affect DNA damage in ALS.

Increased OdG levels have also been observed in the CSF, urine, blood plasma and blood serum of sALS patients [81, 82, 135-137], indicating DNA damage is not just a feature of end-stage of disease. One study suggested levels of DNA damage relate to disease progression, as urine OdG levels correlate negatively with disease progression [81], however, this could not be replicated [136]. Similarly, CSF OdG levels positively correlate with disease duration but not disease severity score [135]. It may be that DNA damage accumulates over time in ALS but does not directly relate to disease progression.

\section{Western Pacific ALS}

Western Pacific ALS, which occurs primarily in Guam and the Japanese Kii peninsula, is clinically very similar to classical sporadic and familial ALS but is suspected of having an environmental cause (reviewed in $[8,138]$ ). Like with sALS and fALS, there is some evidence that DNA damage may be involved in motor neuron degeneration in Western Pacific ALS. A decline in the incidence of Western Pacific ALS was associated with reduced use of traditional foods or medicines containing material from local cycad plants [139]. Cycad seeds contain neurotoxins, including methylazoxymethanol (MAM), $\beta$-N-methylamino-L-alanine (BMAA) and $\beta$-sitosterol $\beta$-d-glucoside [140-142]. It remains debated which, if any, of these toxins causes Western Pacific ALS, but each induces motor impairment and/or motor neuron abnormalities when administered to animals [138, 143, 144]. Interestingly, MAM treatment increases expression of alkylation DNA damage markers in rat cortical neurons and mice, such as $N^{7}$-methyldeoxyguanosine 
and $O^{6}$-methyldeoxyguanosine [145, 146], and BMAA treatment increases $\gamma \mathrm{H} 2 \mathrm{AX}$ expression in primary human neurons [147] and genomic instability in human blood cells [148]. Taken together, this could suggest cycad neurotoxins induce motor neuron degeneration and ALS-like symptoms through DNA damage. However, there are arguments against the cycad hypothesis of Western Pacific ALS (reviewed in [149]), and it remains unproven whether cycad toxins cause Western Pacific ALS and consequently whether DNA damage may be the mechanism involved.

\section{Link between defects in protein degradation and DNA damage in ALS}

Protein misfolding and aggregation is a hallmark of ALS [151]. The presence of insoluble inclusions containing misfolded proteins increases during the course of the disease, thus indicating defects in protein degradation [152]. Several genes associated with fALS encode for proteins that misfold and aggregate into ubiquitinated inclusions within motor neurons [151]. This is the case of SOD1 [153], TDP43 [154] and FUS [107]. In addition, C9ORF72 expansions cause unusual RAN translation that lead to the formation of DPRs, which also accumulate into toxic aggregates [61, 151]. However, this is not exclusive to the familiar forms of ALS since aggregates of ubiquitinated proteins are also present in sALS [155].

The accumulation of misfolded proteins in ALS motor neurons is suggestive of deficient protein degradation mechanisms [156-158]. Consistently, upregulation of protein degradation mechanisms has been successful in clearing toxic aggregates of TDP-43 and FUS [159, 160], as well as SOD1containing inclusions [161]. This is not surprising given that ALS can arise from mutations in genes encoding for proteins involved in degradation mechanisms, including autophagy and/or in the ubiquitin proteasome (UPS) system (Table 1).

Sequestosome 1 (SQSTM1) or p62 is a scaffold protein involved in numerous pathways. P62 was first described by its role as an autophagic receptor [162]. Via its ubiquitinassociated (UBA) domain, p62 recognizes and binds to ubiquitinated substrates and delivers them to autophagososomes through binding to LC3 mediated by its LC3-interacting region (LIR) [163]. P62 is also involved in the degradation of misfolded proteins through the UPS. Through interaction of its PB1 domain to the $26 \mathrm{~s}$ proteasome, p62 facilitates the proteasomal degradation of polyubiquitinated cargos [163]. The presence of inclusions containing p62 has been observed in both fALS and sALS motor neurons, indicating a possible role of p62 in the pathogenesis of the disease [59, 164-166]. In fact, around $2 \%$ of fALS patients carry mutations in the SQSTM1/p62 gene [167].
P62 is itself degraded by autophagy, consequently, impairment of autophagy causes p62 accumulation [162]. Accumulation of p62 has been shown to negatively impact DNA repair in C9ORF72-ALS models [59, 67]. The LIMbinding (LB) domain of p62 was shown to interact with the MIU1 domain of RNF168, an E3 ubiquitin ligase responsible for ubiquitinating histone $\mathrm{H} 2 \mathrm{~A}$ at lysine 15 during DDR [168]. This histone modification signals for the recruitment and stabilization of 53BP1 at the chromatin, thus promoting NHEJ repair [169]. Binding of p62 inhibits RNF168 activity, resulting in defective 53BP1 foci formation [168]. Accordingly, C9ORF72-ALS cell models presented defects in 53BP1 signaling, together with a lack of H2A ubiquitination and ATM phosphorylation. These findings suggested p62 involvement and, indeed, p62 ablation restored 53BP1 recruitment [59]. This indicates DNA repair defects and consequent accumulation of DNA damage in ALS could be the consequence of impaired autophagy mechanisms.

In addition, p62 was also found to form cytoplasmic ubiquitin-positive inclusions with TDP-43 in brains from frontotemporal dementia (FTD) patients, indicating p62 is involved in the degradation of misfolded TDP-43 [166]. The LIR domain of p62 is crucial to clear TDP-43 inclusions since the removal of LIR domain resulted in a build-up of TDP-43 aggregates [170]. In support of these findings, L341V and D337E mutations in the LIR domain of p62 have been identified in ALS patients [171]. It is possible that these mutations contribute to ALS pathogenesis by promoting TDP-43 aggregation into cytoplasmic inclusions. TDP43 mislocalisation and aggregation have a negative impact on DDR [172]. Therefore, p62 mutations could also indirectly interfere with the role of TDP-43 as a DDR player, thus feeding into the DNA repair defects in ALS and further promoting the accumulation of unrepaired damage.

Additional to its role in protein degradation, p62 is also involved in regulating oxidative stress response [162]. Under oxidative stress, p62 binds to Keap1 through its Keap1-interaction region (KIR) [173]. This interaction frees Nrf2 from the inhibitory interaction with Keap1, thus promoting Nrf2 translocation to the nucleus where it acts as a transcription factor for the expression of antioxidant genes [174]. P62 ${ }^{\mathrm{P} 348 \mathrm{~L}}$ and $\mathrm{p} 62^{\mathrm{G} 351 \mathrm{~A}}$ mutants were found in ALS patients and affect KIR domain of p62. These mutations interfere with p62 ability to bind to Keap1 and thus exhibit reduced Nrf2 activity [175]. Moreover, two p62 mutations found in FTD patients, A381V and K238del, were associated with defects in mitochondrial membrane potential and limited mitochondrial substrates [176]. It is likely these mutations contribute to ROS accumulation and consequent increase in oxidative stress due to the absence of Nrf2 protective effect. In fact patient cells carrying A381V and K238del mutations exhibit increased ROS production and concomitant with aggravated oxidative stress [176]. 
Another protein involved in both UPS and autophagy mechanisms is the valosin-containing protein (VCP) or p97, a member of the AAA + family of proteins [177]. Additionally, VCP also promotes NHEJ repair signaling by facilitating the binding of 53BP1 to the histone mark H4K20 after removing the Polycomb protein L3MBTL1 from the chromatin [178]. Mutations affecting VCP have also been identified in ALS patients $[179,180]$. The R155H mutant was found to cause defects in autophagosome maturation. Furthermore, this mutant was found to induce TDP-43 translocation to the cytoplasm, leading to the formation of ubiquitinated TDP-43-positive inclusions [179, 181]. Another VCP-ALS mutant, the R159H, was also found to promote the formation of aggregates containing p62 and TDP-43 [179]. As suggested for p62-mediated ALS pathogenesis, it is likely that $V C P$-ALS mutations might interfere with TDP-43 function as a DDR factor, causing defective DNA repair and accumulation of DNA damage. Additional ALScausing mutations were found to interfere with the ATPase activity of VCP [67, 182], which is crucial for its activity in DDR [183]. The functional relevance of these mutations in the context of the DDR role of VCP is still unknown, but it is possible these VCP mutations cause ALS, in part, by triggering DDR defects and leading to DNA damage accumulation.

Thus, defects in protein degradation mechanisms are linked to the DNA repair defects observed in ALS. This suggests increased DNA damage might be a consequence of the increased protein misfolding and aggregation characteristic of ALS pathology. However, the fact that several ALS-causing mutations affect proteins directly or indirectly involved in DNA repair, thus leading to accumulation of DNA damage, indicates that DNA damage could be a direct cause for motor neuron degeneration. Likely, the accumulation of DNA damage is a combination of cause and effect, both involved in the pathogenesis of ALS.

\section{Astrocytes and ALS}

\section{Astrocytes and brain function}

Astrocytes are the most abundant cell type in the brain and are proposed to have a number of roles in promoting neuron activity. Astrocytes can regulate blood flow to the brain in response to changes in neuron firing, modulate synaptic transmission by secreting glutamate, and take up glutamate to prevent toxic accumulation [184]. Similarly to microglia, astrocytes are thought to exist in two states: a normal 'resting' state, and an activated 'reactive' state. Reactive astrocytes are thought to be activated following injury to the central nervous system, and respond to injury by becoming phagocytic to clear debris and dead cells, releasing factors to promote neuron survival and helping with scar formation to isolate the site of injury or infection, or repair the blood-brain barrier [185]. Importantly, reactive astrogliosis is a key pathological feature of ALS [186, 187], indicating an important role for astrocytes in ALS pathogenesis.

\section{Astrocyte toxicity and ALS}

Astrocyte toxicity in ALS is the most studied of the toxic interactions between glia and neurons in this disease and it appears consistent across sALS and fALS. Astrocytes were first suggested to be involved in SOD1-ALS, as selective astrocyte knockdown of mutant SOD1 in a SOD1 mouse model delayed disease progression and extended survival [188]. It has since been shown that co-culturing motor neurons with astrocytes from sALS, C9ORF72-ALS and SODIALS patients, as well as from SOD1-ALS and FUS-ALS mouse models induces neurodegeneration [16, 18, 189-195]. ALS astrocytes have been suggested to be specifically toxic to motor neurons as they do not induce neurodegeneration in GABAergic or dorsal root ganglion neurons [16, 189-191].

The exact mechanisms by which ALS astrocytes induce motor neuron death remain unclear, however, it is clear that astrocyte secreted factors play a major role, as the application of ALS astrocyte conditioned media alone is sufficient to induce neuron death [16, 18, 189-191, 193]. Secretion of extracellular vesicles has been suggested as a vehicle for the delivery of toxic compounds as the application of C9ORF72-ALS or SOD1-ALS astrocyte exosomes is sufficient to induce motor neuron death $[196,197]$. C9ORF72ALS exosome toxicity was partly attributed to microRNAs in the exosomes [196], which is likely specific to the C9ORF72-ALS subtype as expression profiling of exosomal microRNAs from SOD ${ }^{\mathrm{G} 93 \mathrm{~A}}$ mouse astrocytes showed no significant changes compared to wild-type [195]. SOD1 and TDP-43 protein have also been detected in exosome fractions of cells expressing human SOD1 or TDP-43, respectively [198, 199], suggesting exosomes may also allow the transmission of pathological ALS proteins.

\section{Astrocytes and DNA damage}

While no studies have directly looked at whether astrocytes contribute to DNA damage in ALS, there are some indications that their toxicity to motor neurons could be related to DNA damage (Fig. 4). ALS astrocyte conditioned media has been shown to induce p62 accumulation in motor neurons, concomitant with autophagy impairment [18]. While p62 is primarily known for its involvement in autophagy, it is also a negative regulator of the DDR through its inhibition of the E3 ligase, RNF168, which ubiquitinates histone $\mathrm{H} 2 \mathrm{~A}$ following DNA damage [168]. As covered in a previous section, histone ubiquitination is needed for DDR factor recruitment, thus astrocyte-induced p62 accumulation could affect DDR 
Fig. 4 Possible mechanisms for ALS astrocyte-induced DNA damage (Created with Biorender.com). ALS astrocytes secrete various factors that could induce DNA damage in motor neurons. DPRs secreted by $C 9 O R F 72-A L S$ astrocytes could sequester DDR factors, induce increases in reactive oxygen species and R-loops and induce chromatin compaction. ALS astrocytes are known to induce p62 accumulation in neurons, which could consequently interfere with DDR recruitment to DNA damage. Transmission of pathological proteins like TDP-43 and SOD1 could sequester wild type protein and potentially affect the DDR. Similarly, microRNAs transmitted by ALS astrocytes could affect DDR factors

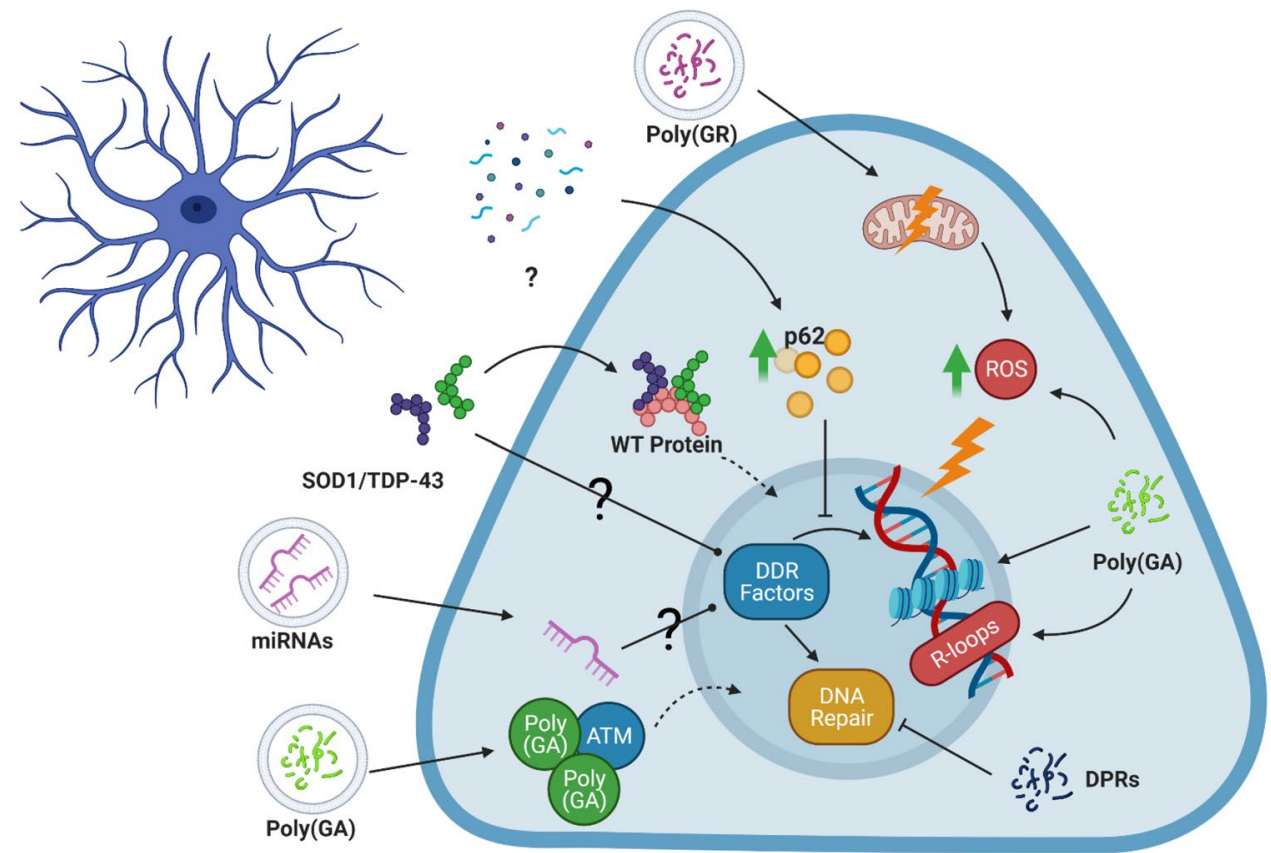

factor recruitment to sites of DNA damage and consequently reduce the efficiency of DNA repair [59].

Autophagy deficiency caused by ALS astrocyte conditioned media could also lead to increased misfolding of pathological proteins and contribute to the depletion of important DDR factors, such as TDP-43. TDP-43 expression does not appear affected by ALS astrocyte conditioned media treatment [18], but this does not discount the possibility of TDP43 mislocalisation or aggregation. Indeed wild-type reactive astrocytes, which behave similarly to ALS astrocytes, induce TDP-43 and SOD1 inclusions in motor neurons [200]. SOD1 expression has also been shown to be increased in cells treated with ALS astrocyte conditioned media, which could not be rescued by autophagy activation, indicating deficient autophagy is not responsible for astrocyte-induced SOD1 expression changes in motor neurons [18].

In addition to inducing protein misfolding through autophagy impairment, ALS astrocytes may also directly transmit pathological proteins to motor neurons. Natively folded and misfolded SOD1 have been shown to be transmitted intercellularly by SOD1-expressing neuronal and nonneuronal cells through exosomes [198]. This is also true of SOD1-ALS astrocytes as mutant SOD1 has been detected in both exosome-enriched and exosome-depleted fractions of mouse SOD $1^{\mathrm{G} 93 \mathrm{~A}}$ primary astrocyte conditioned media [197]. Notably, despite SOD $1^{\mathrm{G} 93 \mathrm{~A}}$ astrocytes secreting less total protein than wild-type astrocytes, $\mathrm{SOD} 1^{\mathrm{G} 93 \mathrm{~A}}$ astrocytes secrete higher levels of SOD1 and intriguingly, VCP [197]. Application of SOD $1{ }^{\mathrm{G} 93 \mathrm{~A}}$ primary astrocyte exosomes has been shown to lead to transmission of SOD1 to motor neurons and motor neuron death [197]. As discussed previously, there is evidence that expression of mutant SOD1 in motor neurons leads to DNA damage and DDR impairment, which would be exacerbated by astrocyte transmission of SOD1.

SOD1 is not the only pathological protein that may be transmitted by ALS astrocytes. TDP-43 has been detected in the exosome fractions of neuron-like cells expressing wild type or mutant TDP-43, and in exosome fractions from healthy mouse primary neurons, but not astrocyte or microglial exosome fractions [199]. This indicates ALS astrocytes may not transmit TDP-43, however, as the study used healthy mice it is unclear whether the same would occur under disease conditions. DPRs may also be transmitted by C9ORF72-ALS astrocytes, which have been shown to express poly(GP) DPRs [201], and likely express other DPRs although this has not yet been shown. It has previously been shown that DPR-expressing motor neurons can transmit DPRs to non-expressing cells, including astrocytes, through both exosome dependent and independent pathways [17]. Although DPR transmission from astrocytes to motor neurons has not been demonstrated yet, this process could exacerbate the existing DPR burden in motor neurons and lead to further DPR-induced DNA damage and DDR dysfunction.

MicroRNAs transmitted by astrocytes could also influence DNA damage and DDR signalling in motor neurons as some species of microRNAs are involved in the promotion or inhibition of DDR signalling and/or DNA repair [202]. Some of the microRNAs identified as dysregulated in C9ORF72ALS astrocyte exosomes [196] have been predicted to target proteins involved in DDR and DNA repair pathways, including miR-140 (NHEJ), miR-200 (cell cycle), miR-494 (transcription-coupled NER), and miR-758 (HR) [202]. miR-494, 
Table 4 Summary of studies of DNA damage in ALS

\begin{tabular}{|c|c|c|c|c|c|c|}
\hline Type of ALS & Model & Tissue/cell type & Controls & DNA damage assay & Method & Reference \\
\hline C9ORF72-ALS & Patient iPSCs & $\begin{array}{l}\text { hiPSC-derived motor } \\
\text { neurons }\end{array}$ & $\begin{array}{l}\text { Age-matched healthy } \\
\text { controls }\end{array}$ & Comet assay, $\gamma \mathrm{H} 2 \mathrm{AX}$ & ICC & {$[56]$} \\
\hline C9ORF72-ALS & Post-mortem & Spinal cord & $\begin{array}{l}\text { Sex-matched non- } \\
\text { ALS controls }\end{array}$ & $\gamma \mathrm{H} 2 \mathrm{AX}$ & IHC & [59] \\
\hline C9ORF72-ALS & $\begin{array}{l}\text { Post-mortem, cell } \\
\text { model }\end{array}$ & $\begin{array}{l}\text { Lumbar spinal cord, } \\
\text { SH-SY5Y human } \\
\text { neuroblastoma cells } \\
\text { transfected with } \\
\text { DRPs }\end{array}$ & $\begin{array}{l}\text { Age-matched healthy } \\
\text { control tissue, cells } \\
\text { expressing empty } \\
\text { vector }\end{array}$ & $\gamma \mathrm{H} 2 \mathrm{AX}, 53 \mathrm{BP} 1$ & $\begin{array}{l}\text { ICC, IHC, immu- } \\
\text { noblot }\end{array}$ & {$[58]$} \\
\hline C9ORF72-ALS & Patient iPSCs & $\begin{array}{l}\text { hiPSC-derived motor } \\
\text { neurons }\end{array}$ & Unaffected controls & $\gamma \mathrm{H} 2 \mathrm{AX}$ & Western blotting & {$[60]$} \\
\hline $\begin{array}{l}\text { C9ORF72- } \\
\text { ALS, NEK1- } \\
\text { ALS }\end{array}$ & Patient iPSCs & $\begin{array}{l}\text { hiPSCs and hiPSC- } \\
\text { derived motor } \\
\text { neurons }\end{array}$ & $\begin{array}{l}\text { Unspecified control } \\
\text { cell lines }\end{array}$ & Comet assay, $\gamma \mathrm{H} 2 \mathrm{AX}$ & ICC & {$[57]$} \\
\hline FUS-ALS & Mouse model & $\begin{array}{l}\text { Cortex and spinal } \\
\text { cord }\end{array}$ & Non-transgenic mice & Comet assay, $\gamma \mathrm{H} 2 \mathrm{AX}$ & $\begin{array}{l}\text { IHC, Western blot- } \\
\text { ting }\end{array}$ & [108] \\
\hline FUS-ALS & Post-mortem & Motor cortex & NND controls & $\gamma \mathrm{H} 2 \mathrm{AX}$ & IHC & {$[105]$} \\
\hline FUS-ALS & $\begin{array}{l}\text { Post-mortem, patient } \\
\text { iPSCs }\end{array}$ & $\begin{array}{l}\text { Lumbar spinal cord, } \\
\text { hiPSC-motor } \\
\text { neurons }\end{array}$ & $\begin{array}{l}\text { Age-matched healthy } \\
\text { control tissue and } \\
\text { cells and isogenic } \\
\text { control cells }\end{array}$ & $\gamma \mathrm{H} 2 \mathrm{AX}$ & ICC, IHC & [106] \\
\hline FUS-ALS & Patient iPSCs & hiPSC-motor neurons & $\begin{array}{l}\text { Healthy controls and } \\
\text { isogenic controls }\end{array}$ & Comet assay, $\gamma \mathrm{H} 2 \mathrm{AX}$ & ICC & [107] \\
\hline sALS & Patient tissue & Blood serum & $\begin{array}{l}\text { Healthy age and sex- } \\
\text { matched controls }\end{array}$ & OdG & ELISA & [137] \\
\hline$s \mathbf{A L S}$ & Patient tissue & Bone marrow MSCs & Healthy controls & $\gamma \mathbf{H} 2 \mathrm{AX}$ & ICC & [133] \\
\hline sALS & Patient tissue & CSF & $\begin{array}{l}\text { Healthy age-matched } \\
\text { controls }\end{array}$ & OdG & HPLC & [135] \\
\hline sALS & Patient tissue & Urine & $\begin{array}{l}\text { Healthy relatives as } \\
\text { controls }\end{array}$ & OdG & ELISA, HPLC & [136] \\
\hline$s \mathbf{A L S}$ & Patient tissue & Whole blood & $\begin{array}{l}\text { Age-matched con- } \\
\text { trols }\end{array}$ & Comet assay & N/A & [132] \\
\hline sALS & Patient tissue & Dermic fibroblasts & $\begin{array}{l}\text { Healthy age and sex- } \\
\text { matched controls }\end{array}$ & $\gamma \mathrm{H} 2 \mathrm{AX}$ & ICC & [134] \\
\hline sALS, fALS & Patient tissue & $\mathrm{CSF}$ & Healthy controls & OdG & ELISA & [82] \\
\hline sALS, fALS & Patient tissue & $\begin{array}{c}\text { Urine, CSF and } \\
\text { blood plasma }\end{array}$ & $\begin{array}{l}\text { OND and healthy } \\
\text { controls }\end{array}$ & OdG & LCEC & {$[81]$} \\
\hline sALS, fALS & Post-mortem & $\begin{array}{l}\text { Whole spinal cord, } \\
\text { motor cortex }\end{array}$ & $\begin{array}{l}\text { OND and healthy } \\
\text { controls }\end{array}$ & OdG & HPLC, IHC & {$[13]$} \\
\hline sALS, fALS & Post-mortem & $\begin{array}{l}\text { Motor cortex, fron- } \\
\text { tal cortex }\end{array}$ & $\begin{array}{l}\text { Mild cognitive } \\
\text { impairment and } \\
\text { healthy controls }\end{array}$ & $\gamma \mathrm{H} 2 \mathrm{AX}$, OdG & IHC & {$[150]$} \\
\hline sALS, fALS & Post-mortem & $\begin{array}{l}\text { Motor cortex, spinal } \\
\text { cord }\end{array}$ & $\begin{array}{l}\text { OND and age- } \\
\text { matched controls }\end{array}$ & AP sites, OdG & AP assay, IHC & [103] \\
\hline SOD1-ALS & Cell model & $\begin{array}{l}\text { Human neuroglioma } \\
\text { cells transfected } \\
\text { with mutant SOD1 }\end{array}$ & $\begin{array}{l}\text { Untransfected and } \\
\text { wild-type SOD1 } \\
\text { transfected cells }\end{array}$ & Comet assay & N/A & [89] \\
\hline SOD1-ALS & Cell model & $\begin{array}{l}\text { SH-SY5Y human } \\
\text { neuroblastoma cells } \\
\text { transfected with } \\
\text { mutant SOD1 }\end{array}$ & $\begin{array}{l}\text { Untransfected and } \\
\text { wild-type SOD1 } \\
\text { transfected cells }\end{array}$ & Comet assay, OdG & HPLC & [91] \\
\hline SOD1-ALS & Cell model & $\begin{array}{l}\text { Immortalised mouse } \\
\text { motor neuron line } \\
\text { NSC34 transfected } \\
\text { with mutant SOD1 }\end{array}$ & $\begin{array}{l}\text { Untransfected and } \\
\text { wild-type SOD1 } \\
\text { transfected cells }\end{array}$ & Comet assay & N/A & [90] \\
\hline
\end{tabular}


Table 4 (continued)

\begin{tabular}{|c|c|c|c|c|c|c|}
\hline Type of ALS & Model & Tissue/cell type & Controls & DNA damage assay & Method & Reference \\
\hline SOD1-ALS & Cell model & $\begin{array}{l}\text { NSC34 cells trans- } \\
\text { fected with mutant } \\
\text { SOD1 }\end{array}$ & $\begin{array}{l}\text { Untransfected and } \\
\text { wild-type SOD1 } \\
\text { transfected cells }\end{array}$ & OdG & ELISA & [92] \\
\hline SOD1-ALS & Cell model & $\begin{array}{l}\text { NSC34 cells stably } \\
\text { expressing mutant } \\
\text { SOD1 }\end{array}$ & $\begin{array}{l}\text { NSC34 cells stably } \\
\text { expressing wild } \\
\text { type hSOD1 }\end{array}$ & $\gamma \mathrm{H} 2 \mathrm{AX}$ & ICC & [93] \\
\hline SOD1-ALS & Mouse model & $\begin{array}{l}\text { Cervical and tho- } \\
\text { racic spinal cord, } \\
\text { primary motor } \\
\text { neurons and } \\
\text { astrocytes }\end{array}$ & Wild type mice & $\begin{array}{l}\text { Comet assay, } \\
\text { 53BP1, } \gamma \mathrm{H} 2 \mathrm{AX}\end{array}$ & IHC, ICC & [83] \\
\hline SOD1-ALS & Mouse model & Lumbar spinal cord & $\begin{array}{l}\text { Age-matched wild } \\
\text { type mice }\end{array}$ & OdG & IHC & [85] \\
\hline SOD1-ALS & Mouse model & $\begin{array}{l}\text { Spinal cord, cortex } \\
\text { and striatum }\end{array}$ & Age-matched mice & OdG & HPLC & [86] \\
\hline SOD1-ALS & Mouse model & Whole spinal cord & $\begin{array}{l}\text { Age-matched wild } \\
\text { type mice }\end{array}$ & OdG & HPLC & [84] \\
\hline SOD1-ALS & Mouse model & $\begin{array}{l}\text { Cervical and lumbar } \\
\text { spinal cord }\end{array}$ & $\begin{array}{l}\text { hSOD1 }{ }^{\mathrm{G} 93 \mathrm{~A}} \text {-negative } \\
\text { mice }\end{array}$ & $\gamma \mathrm{H} 2 \mathrm{AX}$ & $\mathrm{IHC}$ & [97] \\
\hline SOD1-ALS & Mouse model & Spinal cord & Wild type mice & $\gamma \mathrm{H} 2 \mathrm{AX}$ & IHC & [87] \\
\hline$T A R D B P$-ALS & Patient iPSCs & $\begin{array}{l}\text { hiPSC-motor neu- } \\
\text { rons }\end{array}$ & Healthy controls & $\gamma \mathbf{H} 2 \mathrm{AX}$ & ICC & [116] \\
\hline$T A R D B P$-ALS & Patient tissue & Spinal cord extract & $\begin{array}{l}\text { Age-matched con- } \\
\text { trols }\end{array}$ & $\gamma \mathrm{H} 2 \mathrm{AX}$ & IHC, Western & [117] \\
\hline Unspecified & Post-mortem & Cervical spinal cord & $\begin{array}{l}\text { Age-matched con- } \\
\text { trols }\end{array}$ & OdG & HPLC & [14] \\
\hline
\end{tabular}

Rows in Italic indicate papers where no increase in DNA damage was observed, remainder found increase in DNA damage

$O N D$ other neurological disease, $N N D$ non-neurological disease, ICC immunocytochemistry, IHC immunohistochemistry, ELISA enzyme-linked immunosorbent assay, HPLC high-performance liquid chromatography, $L C E C$ liquid chromatography with electrochemical detection

which is downregulated in C9ORF72-ALS astrocytes and extracellular vesicles [196], has also been shown to repress the expression of nucleolin [203]. Nucleolin is an RNA binding protein that plays a number of roles within the cell, including a role in DDR signalling and DNA DSB repair [204]. It would be predicted that miR-494 downregulation in C9ORF72-ALS astrocyte exosomes would lead to increased nucleolin expression in motor neurons. Increased nucleolin has previously been shown to confer increased DNA repair activity [205]. On the other hand, poly(GR) and poly(PR) DPRs co-localise with nucleolin and have been suggested to interfere with some nucleolin functions [65, 206, 207]. An increase in nucleolin could potentially enhance recruitment of DPRs to the nucleus and facilitate the DNA damage they induce. Notably, RNA interference of nucleolin increased the viability of poly(GR)-expressing Drosophila [207]. Thus microRNAs secreted by ALS astrocytes may affect DNA damage signalling and repair in motor neurons. It is, however, worth remembering that microRNAs play a number of varied roles, and while we have linked some ALS astrocyte microRNAs to the DDR further studies would have to be conducted to prove these links.

\section{DNA repair in astrocytes}

Like all cells, astrocytes can be subjected to DNA damage and have mechanisms in place to repair the damage. Interestingly, healthy astrocytes have been shown to exhibit reduced DDR signalling compared to other cell types. Expression of the DDR factors ATM, ATR, MRE11, MDC1, CHK2 and p53 are reduced in terminally differentiated astrocytes compared to neural stem cells [208]. Consequently, astrocytes show limited pATM foci formation and no detectable 53BP1 foci following DNA damage induction by irradiation [208]. Despite this reduced DDR signalling, astrocytes still show normal $\gamma \mathrm{H} 2 \mathrm{AX}$ foci formation, which appears to be in part due to phosphorylation by DNA-PK [208]. ALS astrocytes are also capable of $\gamma \mathrm{H} 2 \mathrm{AX}$ foci formation, with comparable levels of $\gamma \mathrm{H} 2 \mathrm{AX}$ observed when comparing C9ORF72-ALS patient iPSC-derived astrocytes [56] and primary astrocytes from embryonic SOD1-ALS mice [83] to healthy control astrocytes.

Despite astrocyte deficiencies in normal DDR signalling, they are highly radioresistant and capable of repairing DNA damage. Following DNA damage induction, 
Fig. 5 Proposed model for increased DNA damage in ALS. Increased DNA damage could arise through either an increase in exposure to genotoxic agents or a reduction in DNA repair mechanisms. An increase in genotoxic agents could occur through either exposure or generation of new toxic agents or an increase in existing agents. Reduced DNA repair could be due to defects in DNA repair pathways or because of inhibition or loss of components in the DNA damage response

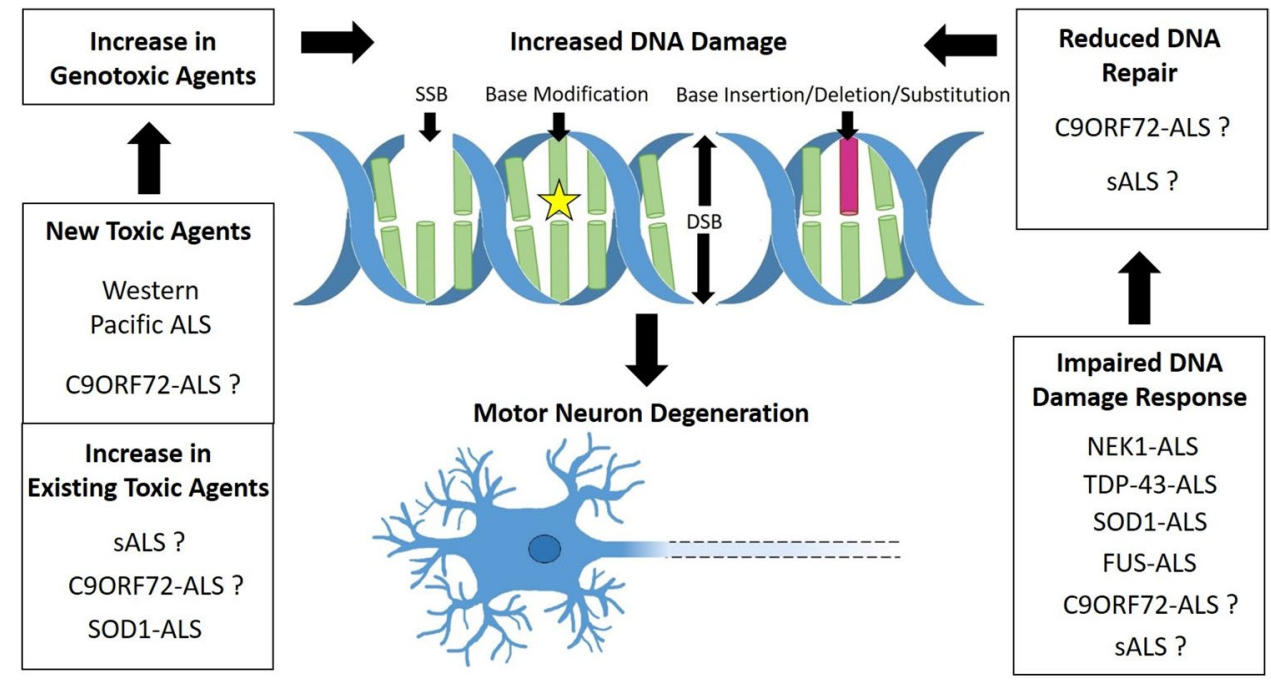

astrocytes exhibit increased expression of the NHEJ factors, $\mathrm{Ku} 70$ and XRCC4, and increased expression of the HR factors, RAD51 and RPA [209]. Despite this, like neurons, astrocytes show an age-related increase in DNA damage, indicating a reduced capacity to repair DNA with age [210]. BER activity has been shown to be reduced in aged astrocytes compared to young astrocytes, however, this is not unique to astrocytes and has also been observed in neurons [210]. Similarly, both neurons and astrocytes have been shown to have reduced NER capabilities compared to fibroblasts indicating general CNS cells may have different DNA repair capabilities and mechanisms compared to non-CNS cells [211]. There is some evidence that among glial cells, astrocytes are more efficient at DNA repair, as studies have shown that mitochondrial DNA oxidative damage [212] and $\mathrm{O}^{6}$-methylguanine [213] are more efficiently repaired in astrocytes than oligodendrocytes or microglia. It remains unknown whether DNA repair is affected in ALS astrocytes. However, PARP expression has been suggested to be increased in sALS astrocytes compared to controls, which could indicate DDR dysfunction [130]. Additionally, overexpressing SIRT6, which is involved in DDR and DNA repair, in primary astrocytes from SOD1-ALS mice reduces their toxicity to motor neurons [214].

\section{Conclusion}

DNA damage is a common feature of sALS and fALS motor neurons (Table 4), and has been implicated in Western Pacific ALS, strongly suggesting it is involved in motor neuron degeneration. It remains unproven whether DNA damage is a direct cause of motor neuron degeneration in ALS or whether it is a consequence of other disease mechanisms. While several genes associated with fALS are thought to play a role in the DDR, they also have several other functions within the cell which may have a greater contribution to motor neuron degeneration. It is also worth noting the current limitations of the field. Most of the studies examining mechanisms of DNA damage in ALS have used 2D cell culture models, which are inherently limited at capturing the complexity of in vivo systems, and the field would benefit from using more relevant models, such as 3D organoid cultures [215]. In addition, many of the studies described in this review have used low-resolution methods to study DNA damage in ALS, and none so far have attempted to profile DNA damage across the genome, as has been done recently in neurons [216].

Increased DNA damage in ALS cells could occur through two general mechanisms: DDR dysfunction or increased DNA damage agents. We propose that most forms of ALS are affected by at least one of these mechanisms (Fig. 5). DNA repair is thought to be less efficient in post-mitotic cells like motor neurons which, with other factors, could contribute to the vulnerability of motor neurons in ALS. Additionally, we discussed recent evidence indicating that ALS astrocytes may contribute to DNA damage in motor neurons and hasten motor neuron death through various mechanisms, including secretion of misfolded proteins and induction of autophagy dysregulation. Thus, boosting DNA repair or DDR pathways, or decreasing genotoxic agents could provide therapeutic benefit in ALS. In addition, evidence indicates that targeting ALS astrocytes with the aim to restore endogenous functions is a promising therapeutic strategy [217].

Author contributions JRK wrote the article. CDSS, NPSFE-K, LF reviewed and edited the manuscript. 
Funding This work was supported by an iCase Studentship from the MRC Discovery Medicine North (DiMeN) Doctoral Training Partnership (MR/R015902/1) in collaboration with AstraZeneca. LF is supported by the Academy of Medical Sciences (grant\# SBF002\1142) and the UKRI (MR/W00416X/1) and CDSS is a fellow of the AstraZeneca Postdoc Programme. SFE-K is supported by a Wellcome Trust Investigator Award (103844) and a Lister Institute of Preventative Medicine Fellowship (137661)

Availability of data and material Not applicable.

Code availability Not applicable.

\section{Declarations}

Conflict of interest The authors declare that they have no conflict of interest.

Ethics approval Not applicable.

Consent to participate Not applicable.

Consent for publication Not applicable.

Open Access This article is licensed under a Creative Commons Attribution 4.0 International License, which permits use, sharing, adaptation, distribution and reproduction in any medium or format, as long as you give appropriate credit to the original author(s) and the source, provide a link to the Creative Commons licence, and indicate if changes were made. The images or other third party material in this article are included in the article's Creative Commons licence, unless indicated otherwise in a credit line to the material. If material is not included in the article's Creative Commons licence and your intended use is not permitted by statutory regulation or exceeds the permitted use, you will need to obtain permission directly from the copyright holder. To view a copy of this licence, visit http://creativecommons.org/licenses/by/4.0/.

\section{References}

1. Goetz CG (2000) Amyotrophic lateral sclerosis: early contributions of Jean Martin Charcot. Muscle Nerve 23:336-343. https:// doi.org/10.1002/(sici)1097-4598(200003)23:3\%3c336

2. Zarei S, Carr K, Reiley L et al (2015) A comprehensive review of amyotrophic lateral sclerosis. Surg Neurol Int. https://doi.org/ $10.4103 / 2152-7806.169561$

3. Yoshino H, Kimura A (2006) Investigation of the therapeutic effects of edaravone, a free radical scavenger, on amyotrophic lateral sclerosis (Phase II study). Amyotroph Lateral Scler 7:247251. https://doi.org/10.1080/17482960600881870

4. Miller RG, Mitchell JD, Moore DH (2012) Riluzole for amyotrophic lateral sclerosis (ALS)/motor neuron disease (MND). Cochrane Database Syst Rev. https://doi.org/10.1002/14651858. CD001447.pub3

5. Tandan R, Bradley WG (1985) Amyotrophic lateral sclerosis: Part 1. Clinical features, pathology, and ethical issues in management. Ann Neurol 18:271-280. https://doi.org/10.1002/ana. 410180302

6. Byrne S, Walsh C, Lynch C et al (2011) Rate of familial amyotrophic lateral sclerosis: a systematic review and meta-analysis. J Neurol Neurosurg Psychiatry 82:623-627. https://doi.org/10. 1136/jnnp.2010.224501
7. Spencer PS (1987) Guam ALS/Parkinsonism-Dementia: a longlatency neurotoxic disorder caused by "slow toxin(s)" in food? Can J Neurol Sci 14:347-357. https://doi.org/10.1017/S0317 167100037732

8. Spencer PS, Fry RC, Palmer VS, Kisby GE (2012) Western Pacific ALS-PDC: a prototypical neurodegenerative disorder linked to DNA damage and aberrant proteogenesis? Front Neurol 3:180. https://doi.org/10.3389/fneur.2012.00180

9. DeJesus-Hernandez M, Mackenzie IR, Boeve BF et al (2011) Expanded GGGGCC hexanucleotide repeat in noncoding region of C9ORF72 causes chromosome 9p-linked FTD and ALS. Neuron 72:245-256. https://doi.org/10.1016/J.NEURON.2011.09. 011

10. Renton AE, Majounie E, Waite A et al (2011) A hexanucleotide repeat expansion in C9ORF72 is the cause of chromosome 9p21linked ALS-FTD. Neuron 72:257-268. https://doi.org/10.1016/J. NEURON.2011.09.010

11. Rosen DR, Siddique T, Patterson D et al (1993) Mutations in $\mathrm{Cu} / \mathrm{Zn}$ superoxide dismutase gene are associated with familial amyotrophic lateral sclerosis. Nature 362:59-62. https://doi.org/ $10.1038 / 362059 \mathrm{a} 0$

12. Ferraiuolo L, Kirby J, Grierson AJ et al (2011) Molecular pathways of motor neuron injury in amyotrophic lateral sclerosis. Nat Rev Neurol 7:616-630. https://doi.org/10.1038/nrneurol.2011. 152

13. Ferrante RJ, Browne SE, Shinobu LA et al (1997) Evidence of increased oxidative damage in both sporadic and familial amyotrophic lateral sclerosis. J Neurochem 69:2064-2074. https://doi.org/10.1046/j.1471-4159.1997.69052064.x

14. Fitzmaurice PS, Shaw IC, Kleiner HE et al (1996) Evidence for DNA damage in amyotrophic lateral sclerosis. Muscle Nerve 19:797-798

15. Valori CF, Brambilla L, Martorana F, Rossi D (2014) The multifaceted role of glial cells in amyotrophic lateral sclerosis. Cell Mol Life Sci 71:287-297. https://doi.org/10.1007/ s00018-013-1429-7

16. Haidet-Phillips AM, Hester ME, Miranda CJ et al (2011) Astrocytes from familial and sporadic ALS patients are toxic to motor neurons. Nat Biotechnol 29:824-828. https://doi.org/ 10.1038/nbt. 1957

17. Westergard T, Jensen BK, Wen X et al (2016) Cell-to-cell transmission of dipeptide repeat proteins linked to C9orf72ALS/FTD. Cell Rep 17:645-652. https://doi.org/10.1016/j. celrep.2016.09.032

18. Madill M, McDonagh K, Ma J et al (2017) Amyotrophic lateral sclerosis patient iPSC-derived astrocytes impair autophagy via non-cell autonomous mechanisms. Mol Brain. https://doi.org/ 10.1186/s13041-017-0300-4

19. Sreedharan J, Blair IP, Tripathi VB et al (2008) TDP-43 mutations in familial and sporadic amyotrophic lateral sclerosis. Science 319:1668-1672. https://doi.org/10.1126/science.11545 84

20. Kwiatkowski TJ, Bosco DA, LeClerc AL et al (2009) Mutations in the FUS/TLS gene on chromosome 16 cause familial amyotrophic lateral sclerosis. Science 323:1205-1208. https:// doi.org/10.1126/science.1166066

21. Vance C, Rogelj B, Hortobágyi T et al (2009) Mutations in FUS, an RNA processing protein, cause familial amyotrophic lateral sclerosis type 6 . Science 323:1208-1211. https://doi. org/10.1126/science.1165942

22. Kenna KP, van Doormaal PTC, Dekker AM et al (2016) NEK1 variants confer susceptibility to amyotrophic lateral sclerosis. Nat Genet 48:1037-1042. https://doi.org/10.1038/ng.3626

23. Maruyama $\mathrm{H}$, Morino $\mathrm{H}$, Ito $\mathrm{H}$ et al (2010) Mutations of optineurin in amyotrophic lateral sclerosis. Nature 465:223226. https://doi.org/10.1038/nature08971 
24. Fecto F, Yan J, Vemula SP et al (2011) SQSTM1 mutations in familial and sporadic amyotrophic lateral sclerosis. Arch Neurol 68:1440-1446. https://doi.org/10.1001/archneurol. 2011.250

25. Johnson JO, Mandrioli J, Benatar M et al (2010) Exome sequencing reveals VCP mutations as a cause of familial ALS. Neuron 68:857-864. https://doi.org/10.1016/j.neuron.2010.11.036

26. Cui R, Tuo M, Li P, Zhou C (2018) Association between TBK1 mutations and risk of amyotrophic lateral sclerosis/frontotemporal dementia spectrum: a meta-analysis. Neurol Sci 39:811-820

27. Chen YZ, Bennett CL, Huynh HM et al (2004) DNA/RNA helicase gene mutations in a form of juvenile amyotrophic lateral sclerosis (ALS4). Am J Hum Genet 74:1128-1135. https://doi. org/10.1086/421054

28. Helal M, Mazaheri N, Shalbafan B et al (2018) Clinical presentation and natural history of infantile-onset ascending spastic paralysis from three families with an ALS2 founder variant. Neurol Sci 39:1917-1925. https://doi.org/10.1007/s10072-018-3526-8

29. Genin EC, Plutino M, Bannwarth S et al (2016) CHCHD10 mutations promote loss of mitochondrial cristae junctions with impaired mitochondrial genome maintenance and inhibition of apoptosis. EMBO Mol Med 8:58-72. https://doi.org/10.15252/ emmm.201505496

30. Parkinson N, Ince PG, Smith MO et al (2006) ALS phenotypes with mutations in CHMP2B (charged multivesicular body protein 2B). Neurology 67:1074-1077. https://doi.org/10.1212/01.wnl. $0000231510.89311 .8 \mathrm{~b}$

31. Johnson JO, Pioro EP, Boehringer A et al (2014) Mutations in the Matrin 3 gene cause familial amyotrophic lateral sclerosis. Nat Neurosci 17:664-666. https://doi.org/10.1038/nn.3688

32. Wu CH, Fallini C, Ticozzi N et al (2012) Mutations in the profilin 1 gene cause familial amyotrophic lateral sclerosis. Nature 488:499-503. https://doi.org/10.1038/nature11280

33. Deng HX, Chen W, Hong ST et al (2011) Mutations in UBQLN2 cause dominant X-linked juvenile and adult-onset ALS and ALS/ dementia. Nature 477:211-215. https://doi.org/10.1038/natur e10353

34. Nishimura AL, Mitne-Neto M, Silva HCA et al (2004) A mutation in the vesicle-trafficking protein VAPB causes late-onset spinal muscular atrophy and amyotrophic lateral sclerosis. Am J Hum Genet 75:822-831. https://doi.org/10.1086/425287

35. Ghasemi M, Brown RH (2017) Genetics of amyotrophic lateral sclerosis. Cold Spring Harb Perspect Med 8:a024125. https://doi. org/10.1101/cshperspect.a024125

36. Jackson SP, Bartek J (2009) The DNA-damage response in human biology and disease. Nature 461:1071-1078. https://doi. org/10.1038/nature 08467

37. Kazak L, Reyes A, Holt IJ (2012) Minimizing the damage: repair pathways keep mitochondrial DNA intact. Nat Rev Mol Cell Biol 13:659-671. https://doi.org/10.1038/nrm3439

38. Giglia-Mari G, Zotter A, Vermeulen W (2011) DNA damage response. Cold Spring Harb Perspect Biol 3:a000745. https:// doi.org/10.1101/cshperspect.a000745

39. Valavanidis A, Vlachogianni T, Fiotakis C (2009) 8-hydroxy-2' -deoxyguanosine (8-OHdG): A critical biomarker of oxidative stress and carcinogenesis. J Environ Sci Heal Part C 27:120-139. https://doi.org/10.1080/10590500902885684

40. Burma S, Chen DJ (2004) Role of DNA-PK in the cellular response to DNA double-strand breaks. DNA Repair (Amst) 3:909-918

41. Nowsheen S, Yang ES (2012) The intersection between DNA damage response and cell death pathways. Exp Oncol 34:243-254

42. Jeppesen DK, Bohr VA, Stevnsner T (2011) DNA repair deficiency in neurodegeneration. Prog Neurobiol 94:166-200
43. De Waard MC, Van Der Pluijm I, Zuiderveen Borgesius $\mathrm{N}$ et al (2010) Age-related motor neuron degeneration in DNA repairdeficient Ercc1 mice. Acta Neuropathol 120:461-475. https:// doi.org/10.1007/s00401-010-0715-9

44. Katyal S, El-Khamisy SF, Russell HR et al (2007) TDP1 facilitates chromosomal single-strand break repair in neurons and is neuroprotective in vivo. EMBO J 26:4720-4731. https://doi.org/ 10.1038/sj.emboj.7601869

45. Mullaart E, Boerrigter METI, Brouwer A et al (1988) Agedependent accumulation of alkali-labile sites in DNA of postmitotic but not in that of mitotic rat liver cells. Mech Ageing Dev 45:41-49. https://doi.org/10.1016/0047-6374(88)90017-6

46. Iyama T, Wilson DM (2013) DNA repair mechanisms in dividing and non-dividing cells. DNA Repair (Amst) 12:620-636. https:// doi.org/10.1016/J.DNAREP.2013.04.015

47. Sykora P, Yang JL, Ferrarelli LK et al (2013) Modulation of DNA base excision repair during neuronal differentiation. Neurobiol Aging 34:1717-1727. https://doi.org/10.1016/j.neurobiola ging.2012.12.016

48. Nouspikel T, Hanawalt PC (2000) Terminally differentiated human neurons repair transcribed genes but display attenuated global DNA repair and modulation of repair gene expression. Mol Cell Biol 20:1562-1570. https://doi.org/10.1128/mcb.20.5. $1562-1570.2000$

49. Madabhushi R, Gao F, Pfenning AR et al (2015) Activity-induced DNA breaks govern the expression of neuronal early-response genes. Cell 161:1592-1605. https://doi.org/10.1016/j.cell.2015. 05.032

50. Zaksauskaite R, Thomas RC, van Eeden F, El-Khamisy SF (2021) Tdp1 protects from topoisomerase 1-mediated chromosomal breaks in adult zebrafish but is dispensable during larval development. Sci Adv 7:4165. https://doi.org/10.1126/sciadv. abc4165d

51. Martin LJ, Wong M (2017) Enforced DNA repair enzymes rescue neurons from apoptosis induced by target deprivation and axotomy in mouse models of neurodegeneration. Mech Ageing Dev 161:149-162. https://doi.org/10.1016/j.mad.2016.06.011

52. Vasko MR, Guo C, Kelley MR (2005) The multifunctional DNA repair/redox enzyme Ape1/Ref-1 promotes survival of neurons after oxidative stress. DNA Repair (Amst) 4:367-379. https:// doi.org/10.1016/j.dnarep.2004.11.006

53. Kruman II, Wersto RP, Cardozo-Pelaez F et al (2004) Cell cycle activation linked to neuronal cell death initiated by DNA damage. Neuron 41:549-561. https://doi.org/10.1016/S08966273(04)00017-0

54. Cardinale A, Paldino E, Giampà C et al (2015) PARP-1 inhibition is neuroprotective in the R6/2 mouse model of huntington's disease. PLoS ONE. https://doi.org/10.1371/journal.pone.01344 82

55. Abdelkarim GE, Gertz K, Harms C et al (2001) Protective effects of PJ34, a novel, potent inhibitor of poly(ADP-ribose) polymerase (PARP) in in vitro and in vivo models of stroke. Int J Mol Med 7:255-260. https://doi.org/10.3892/ijmm.7.3.255

56. Lopez-Gonzalez R, Lu Y, Gendron TF et al (2016) Poly (GR) in C9ORF72-related ALS/FTD compromises mitochondrial function and increases oxidative stress and DNA damage in iPSCderived motor neurons. Neuron 92:383-391. https://doi.org/10. 1016/J.NEURON.2016.09.015

57. Higelin J, Catanese A, Semelink-Sedlacek LL et al (2018) NEK1 loss-of-function mutation induces DNA damage accumulation in ALS patient-derived motoneurons. Stem Cell Res 30:150-162. https://doi.org/10.1016/J.SCR.2018.06.005

58. Farg MA, Konopka A, Soo KY et al (2017) The DNA damage response (DDR) is induced by the C9orf72 repeat expansion in amyotrophic lateral sclerosis. Hum Mol Genet 26:2882-2896. https://doi.org/10.1093/hmg/ddx170 
59. Walker C, Herranz-Martin S, Karyka E et al (2017) C9orf72 expansion disrupts ATM-mediated chromosomal break repair. Nat Neurosci 20:1225-1235. https://doi.org/10.1038/nn.4604

60. Andrade NS, Ramic M, Esanov R et al (2020) Dipeptide repeat proteins inhibit homology-directed DNA double strand break repair in C9ORF72 ALS/FTD. Mol Neurodegener 15:1-18. https://doi.org/10.1186/s13024-020-00365-9

61. Balendra R, Isaacs AM (2018) C9orf72-mediated ALS and FTD: multiple pathways to disease. Nat Rev Neurol 14:544-558. https://doi.org/10.1038/s41582-018-0047-2

62. Nihei Y, Mori K, Werner G et al (2020) Poly-glycine-alanine exacerbates C9orf72 repeat expansion-mediated DNA damage via sequestration of phosphorylated ATM and loss of nuclear hnRNPA3. Acta Neuropathol 139:99-118. https://doi.org/10. 1007/s00401-019-02082-0

63. Choi SY, Lopez-Gonzalez R, Krishnan G et al (2019) C9ORF72ALS/FTD-associated poly(GR) binds Atp5a1 and compromises mitochondrial function in vivo. Nat Neurosci 22:851-862. https://doi.org/10.1038/s41593-019-0397-0

64. May S, Hornburg D, Schludi MH et al (2014) C9orf72 FTLD/ ALS-associated Gly-Ala dipeptide repeat proteins cause neuronal toxicity and Unc119 sequestration. Acta Neuropathol 128:485503. https://doi.org/10.1007/s00401-014-1329-4

65. Wen X, Tan W, Westergard T et al (2014) Antisense prolinearginine RAN dipeptides linked to C9ORF72-ALS/FTD form toxic nuclear aggregates that initiate in vitro and in vivo neuronal death. Neuron 84:1213-1225. https://doi.org/10.1016/J. NEURON.2014.12.010

66. Yang D, Abdallah A, Li Z et al (2015) FTD/ALS-associated poly(GR) protein impairs the Notch pathway and is recruited by poly(GA) into cytoplasmic inclusions. Acta Neuropathol 130:525-535. https://doi.org/10.1007/s00401-015-1448-6

67. Walker C, El-Khamisy SF (2018) Perturbed autophagy and DNA repair converge to promote neurodegeneration in amyotrophic lateral sclerosis and dementia. Brain 141:1247-1262. https://doi. org/10.1093/brain/awy076

68. Cristini A, Ricci G, Capranico G et al (2019) Dual processing of R-loops and topoisomerase I induces transcription-dependent DNA double-strand breaks. Cell Rep 28:3167-3181. https://doi. org/10.1016/j.celrep.2019.08.041

69. Teng Y, Yadav T, Duan M et al (2018) ROS-induced R loops trigger a transcription-coupled but BRCA1/2-independent homologous recombination pathway through CSB. Nat Commun 9:1-12. https://doi.org/10.1038/s41467-018-06586-3

70. Sordet O, Redon CE, Guirouilh-Barbat J et al (2009) Ataxia telangiectasia mutated activation by transcription- and topoisomerase I-induced DNA double-strand breaks. EMBO Rep 10:887-893. https://doi.org/10.1038/embor.2009.97

71. Alagoz M, Chiang S, Sharma A, El-khamisy SF (2013) ATM deficiency results in accumulation of DNA-topoisomerase I covalent intermediates in neural cells. PLoS ONE 8:e58239. https:// doi.org/10.1371/journal.pone.0058239

72. Usdin K, House NCM, Freudenreich CH (2015) Repeat instability during DNA repair: Insights from model systems. Crit Rev Biochem Mol Biol 50:142-167. https://doi.org/10.3109/10409 238.2014.999192

73. Lopez-Gonzalez R, Yang D, Pribadi M et al (2019) Partial inhibition of the overactivated Ku80-dependent DNA repair pathway rescues neurodegeneration in C9ORF72-ALS/FTD. Proc Natl Acad Sci USA 116:9628-9633. https://doi.org/10.1073/pnas. 1901313116

74. Maor-Nof M, Shipony Z, Lopez-Gonzalez R et al (2021) p53 is a central regulator driving neurodegeneration caused by $\mathrm{C} 9$ orf 72 poly(PR). Cell 184:689-708. https://doi.org/10.1016/j.cell.2020. 12.025
75. Riemslagh FW, Lans H, Seelaar H et al (2019) HR23B pathology preferentially co-localizes with p62, pTDP-43 and poly-GA in C9ORF72-linked frontotemporal dementia and amyotrophic lateral sclerosis. Acta Neuropathol Commun 7:39. https://doi. org/10.1186/s40478-019-0694-6

76. Jin MH, Oh DY (2019) ATM in DNA repair in cancer. Pharmacol Ther 203:107391

77. Davis AJ, Chen DJ (2013) DNA double strand break repair via non-homologous end-joining. Transl Cancer Res 2:130-143

78. Kasten U, Borgmann K, Burgmann P et al (1999) Overexpression of human $\mathrm{Ku} 70 / \mathrm{Ku} 80$ in rat cells resulting in reduced DSB repair capacity with appropriate increase in cell radiosensitivity but with no effect on cell recovery. Radiat Res 151:532-539. https:// doi.org/10.2307/3580029

79. Zou Z-Y, Zhou Z-R, Che C-H et al (2017) Genetic epidemiology of amyotrophic lateral sclerosis: a systematic review and metaanalysis. J Neurol Neurosurg Psychiatry 88:540-549. https://doi. org/10.1136/jnnp-2016-315018

80. Saccon RA, Bunton-Stasyshyn RKA, Fisher EMC, Fratta P (2013) Is SOD1 loss of function involved in amyotrophic lateral sclerosis? Brain 136:2342-2358. https://doi.org/10.1093/brain/ awt097

81. Bogdanov M, Brown RH, Matson W et al (2000) Increased oxidative damage to DNA in ALS patients. Free Radic Biol Med 29:652-658. https://doi.org/10.1016/S0891-5849(00)00349-X

82. Ihara Y, Nobukuni K, Takata H, Hayabara T (2005) Oxidative stress and metal content in blood and cerebrospinal fluid of amyotrophic lateral sclerosis patients with and without a $\mathrm{Cu}, \mathrm{Zn}$ superoxide dismutase mutation. Neurol Res 27:105-108. https:// doi.org/10.1179/016164105X18430

83. Penndorf D, Tadić V, Witte OW et al (2017) DNA strand breaks and TDP-43 mislocation are absent in the murine hSOD1G93A model of amyotrophic lateral sclerosis in vivo and in vitro. PLoS ONE 12:e0183684. https://doi.org/10.1371/JOURNAL.PONE. 0183684

84. Fang L, Teuchert M, Huber-Abel F et al (2010) MMP-2 and MMP-9 are elevated in spinal cord and skin in a mouse model of ALS. J Neurol Sci 294:51-56. https://doi.org/10.1016/J.JNS. 2010.04.005

85. Warita H, Hayashi T, Murakami T et al (2001) Oxidative damage to mitochondrial DNA in spinal motoneurons of transgenic ALS mice. Mol Brain Res 89:147-152. https://doi.org/10.1016/ S0169-328X(01)00029-8

86. Aguirre N, Flint Beal M, Matson WR, Bogdanov MB (2005) Increased oxidative damage to DNA in an animal model of amyotrophic lateral sclerosis. Free Radic Res 39:383-388. https://doi. org/10.1080/10715760400027979

87. Li J, Song Moh MS et al (2019) Cytoplasmic restriction of mutated SOD1 impairs the DNA repair process in spinal cord neurons. Cells 8:1502. https://doi.org/10.3390/cells8121502

88. Torres P, Cacabelos D, Pairada J et al (2020) Gender-specific beneficial effects of docosahexaenoic acid dietary supplementation in G93A-SOD1 amyotrophic lateral sclerosis mice. Neurotherapeutics 17:269-281. https://doi.org/10.1007/ s13311-019-00808-2

89. Brasil AA, Magalhães RSS, De Carvalho MDC et al (2018) Implications of fALS mutations on Sod1 function and oligomerization in cell models. Mol Neurobiol 55:5269-5281. https://doi. org/10.1007/s12035-017-0755-4

90. Sau D, De Biasi S, Vitellaro-Zuccarello L et al (2007) Mutation of SOD1 in ALS: a gain of a loss of function. Hum Mol Genet 16:1604-1618. https://doi.org/10.1093/hmg/ddm110

91. Barbosa LF, Cerqueira FM, Macedo AFA et al (2010) Increased SOD1 association with chromatin, DNA damage, p53 activation, and apoptosis in a cellular model of SOD1-linked ALS. Biochim 
Biophys Acta Mol Basis Dis 1802:462-471. https://doi.org/10. 1016/J.BBADIS.2010.01.011

92. Wang X-D, Zhu M-W, Shan D et al (2019) Spy1, a unique cell cycle regulator, alters viability in ALS motor neurons and cell lines in response to mutant SOD1-induced DNA damage. DNA Repair (Amst) 74:51-62. https://doi.org/10.1016/J.DNAREP. 2018.12.005

93. Zhang C, Yang Y, Liang W et al (2019) Neuroprotection by urate on the mutant hSOD1-related cellular and Drosophila models of amyotrophic lateral sclerosis: Implication for GSH synthesis via activating Akt/GSK3 $3 /$ Nrf2/GCLC pathways. Brain Res Bull 146:287-301. https://doi.org/10.1016/j.brainresbull.2019.01.019

94. Borchelt DR, Lee MK, Slunt HS et al (1994) Superoxide dismutase 1 with mutations linked to familial amyotrophic lateral sclerosis possesses significant activity. Proc Natl Acad Sci USA 91:8292-8296. https://doi.org/10.1073/PNAS.91.17.8292

95. Hayward LJ, Rodriguez JA, Kim JW et al (2002) Decreased metallation and activity in subsets of mutant superoxide dismutases associated with familial amyotrophic lateral sclerosis. J Biol Chem 277:15923-15931. https://doi.org/10.1074/jbc.M1120 87200

96. Liu R, Narla RK, Kurinov I et al (1999) Increased hydroxyl radical production and apoptosis in PC12 neuron cells expressing the gain-of-function mutant G93A SOD1 gene. Radiat Res 151:133-141. https://doi.org/10.2307/3579763

97. Yang YQ, Zheng YH, Zhang CT et al (2020) Wild-type p53induced phosphatase 1 down-regulation promotes apoptosis by activating the DNA damage-response pathway in amyotrophic lateral sclerosis. Neurobiol Dis 134:104648. https://doi.org/10. 1016/j.nbd.2019.104648

98. Gertz B, Wong M, Martin LJ (2012) Nuclear localization of human SOD1 and mutant SOD1-specific disruption of survival motor neuron protein complex in transgenic amyotrophic lateral sclerosis mice. J Neuropathol Exp Neurol 71:162-177. https://doi.org/10.1097/NEN.0b013e318244b635

99. González De Aguilar JL, Gordon JW, René F et al (2000) Alteration of the Bcl-x/Bax ratio in a transgenic mouse model of amyotrophic lateral sclerosis: Evidence for the implication of the p53 signaling pathway. Neurobiol Dis 7:406-415. https:// doi.org/10.1006/nbdi.2000.0295

100. Shaikh AY, Martin LJ (2002) DNA base-excision repair enzyme apurinic/apyrimidinic endonuclease/redox factor-1 is increased and competent in the brain and spinal cord of individuals with amyotrophic lateral sclerosis. NeuroMolecular Med 2:47-60. https://doi.org/10.1007/s12017-002-0038-7

101. Nagano I, Murakami T, Manabe Y, Abe K (2002) Early decrease of survival factors and DNA repair enzyme in spinal motor neurons of presymptomatic transgenic mice that express a mutant SOD1 gene. In: Life sciences. Pergamon, pp 541-548

102. Carroll J, Page TKW, Chiang SC et al (2015) Expression of a pathogenic mutation of SOD1 sensitizes aprataxin-deficient cells and mice to oxidative stress and triggers hallmarks of premature ageing. Hum Mol Genet 24:828-840. https://doi. org/10.1093/hmg/ddu500

103. Kim BW, Jeong YE, Wong M, Martin LJ (2020) DNA damage accumulates and responses are engaged in human ALS brain and spinal motor neurons and DNA repair is activatable in iPSC-derived motor neurons with SOD1 mutations. Acta Neuropathol Commun 8:1-26. https://doi.org/10.1186/ s40478-019-0874-4

104. Ratti A, Buratti E (2016) Physiological functions and pathobiology of TDP-43 and FUS/TLS proteins. J Neurochem 138:95111. https://doi.org/10.1111/jnc. 13625
105. Wang W-Y, Pan L, Su SC et al (2013) Interaction of FUS and HDAC1 regulates DNA damage response and repair in neurons. Nat Neurosci 16:1383-1391. https://doi.org/10.1038/nn.3514

106. Naumann M, Pal A, Goswami A et al (2018) Impaired DNA damage response signaling by FUS-NLS mutations leads to neurodegeneration and FUS aggregate formation. Nat Commun 9:335. https://doi.org/10.1038/s41467-017-02299-1

107. Higelin J, Demestre M, Putz S et al (2016) FUS mislocalization and vulnerability to DNA damage in ALS patients derived hiPSCs and aging motoneurons. Front Cell Neurosci 10:290. https:// doi.org/10.3389/fncel.2016.00290

108. Qiu H, Lee S, Shang Y et al (2014) ALS-associated mutation FUS-R521C causes DNA damage and RNA splicing defects. J Clin Invest 124:981-999. https://doi.org/10.1172/JCI72723

109. Mastrocola AS, Kim SH, Trinh AT et al (2013) The RNA-binding protein fused in sarcoma (FUS) functions downstream of poly(ADP-ribose) polymerase (PARP) in response to DNA damage. J Biol Chem 288:24731-24741. https://doi.org/10.1074/jbc. M113.497974

110. Rulten SL, Rotheray A, Green RL et al (2014) PARP-1 dependent recruitment of the amyotrophic lateral sclerosis-associated protein FUS/TLS to sites of oxidative DNA damage. Nucleic Acids Res 42:307-314. https://doi.org/10.1093/nar/gkt835

111. Hill SJ, Mordes DA, Cameron LA et al (2016) Two familial ALS proteins function in prevention/repair of transcription-associated DNA damage. Proc Natl Acad Sci USA 113:E7701-E7709. https://doi.org/10.1073/pnas.1611673113

112. Kuta R, Larochelle N, Fernandez M et al (2020) Depending on the stress, histone deacetylase inhibitors act as heat shock protein co-inducers in motor neurons and potentiate arimoclomol, exerting neuroprotection through multiple mechanisms in ALS models. Cell Stress Chaperones 25:173-191. https://doi. org/10.1007/s12192-019-01064-1

113. Wang H, Rangaswamy S, Kodavati M et al (2019) RT2 PCR array screening reveals distinct perturbations in DNA damage response signaling in FUS-associated motor neuron disease. Mol Brain. https://doi.org/10.1186/s13041-019-0526-4

114. Neumann M, Sampathu DM, Kwong LK et al (2006) Ubiquitinated TDP-43 in frontotemporal lobar degeneration and amyotrophic lateral sclerosis. Science 314:130-133. https:// doi.org/10.1126/science. 1134108

115. Arai T, Hasegawa M, Akiyama $\mathrm{H}$ et al (2006) TDP-43 is a component of ubiquitin-positive tau-negative inclusions in frontotemporal lobar degeneration and amyotrophic lateral sclerosis. Biochem Biophys Res Commun 351:602-611. https://doi.org/ 10.1016/J.BBRC.2006.10.093

116. Kreiter N, Pal A, Lojewski X et al (2018) Age-dependent neurodegeneration and organelle transport deficiencies in mutant TDP43 patient-derived neurons are independent of TDP43 aggregation. Neurobiol Dis 115:167-181. https://doi.org/10. 1016/J.NBD.2018.03.010

117. Guerrero EN, Mitra J, Wang H et al (2019) Amyotrophic lateral sclerosis-associated TDP-43 mutation Q331K prevents nuclear translocation of XRCC4-DNA ligase 4 complex and is linked to genome damage-mediated neuronal apoptosis. Hum Mol Genet 28:2459-2476. https://doi.org/10.1093/hmg/ddz062

118. Konopka A, Whelan DR, Jamali MS et al (2020) Impaired NHEJ repair in amyotrophic lateral sclerosis is associated with TDP-43 mutations. Mol Neurodegener 15:51. https://doi.org/ 10.1186/s13024-020-00386-4

119. Mitra J, Guerrero EN, Hegde PM et al (2019) Motor neuron disease-associated loss of nuclear TDP-43 is linked to DNA double-strand break repair defects. Proc Natl Acad Sci USA 116:4696-4705. https://doi.org/10.1073/pnas.1818415116

120. Freibaum BD, Chitta RK, High AA, Taylor JP (2010) Global analysis of TDP-43 interacting proteins reveals strong 
association with RNA splicing and translation machinery. J Proteome Res 9:1104-1120. https://doi.org/10.1021/pr901076y

121. Polci R, Peng A, Chen P-L et al (2004) NIMA-related protein kinase 1 is involved early in the ionizing radiation-induced DNA damage response. Cancer Res 64:8800-8803. https://doi. org/10.1158/0008-5472.CAN-04-2243

122. Chen Y, Chen C-F, Riley DJ, Chen P-L (2011) Nek1 kinase functions in DNA damage response and checkpoint control through a pathway independent of ATM and ATR. Cell Cycle 10:655-663. https://doi.org/10.4161/cc.10.4.14814

123. Pelegrini AL, Moura DJ, Brenner BL et al (2010) Nek1 silencing slows down DNA repair and blocks DNA damage-induced cell cycle arrest. Mutagenesis 25:447-454. https://doi.org/10. 1093/mutage/geq026

124. Chen Y, Chen P-L, Chen C-F et al (2008) Never-in-mitosis related Kinase 1 functions in DNA damage response and checkpoint control. Cell Cycle 7:3194-3201. https://doi.org/ $10.4161 /$ cc.7.20.6815

125. Schwartz EI, Smilenov LB, Price MA et al (2007) Cell cycle activation in postmitotic neurons is essential for DNA repair. Cell Cycle 6:318-329. https://doi.org/10.4161/cc.6.3.3752

126. Spies J, Waizenegger A, Barton O et al (2016) Nek1 regulates Rad54 to orchestrate homologous recombination and replication fork stability. Mol Cell 62:903-917. https://doi.org/10. 1016/J.MOLCEL.2016.04.032

127. Alonso A, Logroscino G, Jick SS, Hernán MA (2009) Incidence and lifetime risk of motor neuron disease in the United Kingdom: a population-based study. Eur J Neurol 16:745-751. https://doi.org/10.1111/j.1468-1331.2009.02586.x

128. Gorbunova V, Seluanov A, Mao Z, Hine C (2007) Changes in DNA repair during aging. Nucleic Acids Res 35:7466-7474. https://doi.org/10.1093/nar/gkm756

129. Ingre $C$, Roos PM, Piehl $F$ et al (2015) Risk factors for amyotrophic lateral sclerosis. Clin Epidemiol 7:181-193. https://doi. org/10.2147/CLEP.S37505

130. Kim SH, Henkel JS, Beers DR et al (2003) PARP expression is increased in astrocytes but decreased in motor neurons in the spinal cord of sporadic ALS patients. J Neuropathol Exp Neurol 62:88-103. https://doi.org/10.1093/jnen/62.1.88

131. Kisby GE, Milne J, Sweatt C (1997) Evidence of reduced DNA repair in amyotrophic lateral sclerosis brain tissue. NeuroReport 8:1337-1340. https://doi.org/10.1097/00001756-19970 4140-00004

132. De Benedetti S, Lucchini G, Del Bò C et al (2017) Blood trace metals in a sporadic amyotrophic lateral sclerosis geographical cluster. Biometals 30:355-365. https://doi.org/10.1007/ s10534-017-0011-4

133. Wald-Altman S, Pichinuk E, Kakhlon O, Weil M (2017) A differential autophagy-dependent response to DNA double-strand breaks in bone marrow mesenchymal stem cells from sporadic ALS patients. Dis Model Mech 10:645-654. https://doi.org/10. 1242/dmm.027938

134. Riancho J, Castanedo-Vázquez D, Gil-Bea F et al (2020) ALSderived fibroblasts exhibit reduced proliferation rate, cytoplasmic TDP-43 aggregation and a higher susceptibility to DNA damage. J Neurol. https://doi.org/10.1007/s00415-020-09704-8

135. Murata T, Ohtsuka C, Terayama Y (2008) Increased mitochondrial oxidative damage and oxidative DNA damage contributes to the neurodegenerative process in sporadic amyotrophic lateral sclerosis. Free Radic Res 42:221-225. https://doi.org/10.1080/ 10715760701877262

136. Mitsumoto H, Santella RM, Liu X et al (2008) Oxidative stress biomarkers in sporadic ALS. Amyotroph Lateral Scler 9:177183. https://doi.org/10.1080/17482960801933942
137. Blasco H, Garcon G, Patin F et al (2017) Panel of oxidative stress and inflammatory biomarkers in ALS: a pilot study. Can J Neurol Sci 44:90-95. https://doi.org/10.1017/cjn.2016.284

138. Spencer PS, Nunn PB, Hugon J et al (1987) Guam amyotrophic lateral sclerosis-parkinsonism-dementia linked to a plant excitant neurotoxin. Science 237:517-522. https://doi.org/10.1126/ SCIENCE. 3603037

139. Spencer PS, Palmer VS, Ludolph AC (2005) On the decline and etiology of high-incidence motor system disease in West Papua (southwest New Guinea). Mov Disord 20:S119-S126. https:// doi.org/10.1002/mds.20552

140. Khabazian I, Bains JS, Williams DE et al (2002) Isolation of various forms of sterol $\beta$-D-glucoside from the seed of Cycas circinalis: neurotoxicity and implications for ALS-parkinsonism dementia complex. J Neurochem 82:516-528. https://doi.org/10. 1046/j.1471-4159.2002.00976.x

141. Vega A, Bell EA (1967) $\alpha$-Amino- $\beta$-methylaminopropionic acid, a new amino acid from seeds of Cycas circinalis. Phytochemistry 6:759-762. https://doi.org/10.1016/S0031-9422(00)86018-5

142. Kobayashi A, Matsumoto H (1964) Methylazoxymethanol, the aglycone of cycasin. Fed Proc 23:1354-1356

143. Yamamoto Y, Tanimura T (1989) Effect of prenatal methylazoxymethanol acetate exposure on the motor behavior of the rat offspring. Congenit Anom (Kyoto) 29:51-58. https://doi.org/10. 1111/j.1741-4520.1989.tb00734.x

144. Tabata RC, Wilson JMB, Ly P et al (2008) Chronic exposure to dietary sterol glucosides is neurotoxic to motor neurons and induces an ALS-PDC phenotype. NeuroMolecular Med 10:2439. https://doi.org/10.1007/s12017-007-8020-z

145. Esclaire F, Kisby G, Spencer P et al (1999) The Guam cycad toxin methylazoxymethanol damages neuronal DNA and modulates tau mRNA expression and excitotoxicity. Exp Neurol 155:11-21. https://doi.org/10.1006/EXNR.1998.6962

146. Kisby GE, Fry RC, Lasarev MR et al (2011) The cycad genotoxin MAM modulates brain cellular pathways involved in neurodegenerative disease and cancer in a DNA damage-linked manner. PLoS ONE 6:e20911. https://doi.org/10.1371/journ al.pone.0020911

147. Chiu AS, Gehringer MM, Braidy N et al (2012) Excitotoxic potential of the cyanotoxin $\beta$-methyl-amino-L-alanine (BMAA) in primary human neurons. Toxicon 60:1159-1165. https://doi. org/10.1016/J.TOXICON.2012.07.169

148. Gerić M, Gajski G, Domijan AM et al (2019) Genotoxic effects of neurotoxin $\mathrm{B}-\mathrm{N}$-methylamino-L-alanine in human peripheral blood cells. Chemosphere 214:623-632. https://doi.org/ 10.1016/j.chemosphere.2018.09.155

149. Borenstein AR, Mortimer JA, Schellenberg GD et al (2009) The ALS/PDC syndrome of Guam and the cycad hypothesis. Neurology 72:473-476. https://doi.org/10.1212/01.wnl.00003 44257.59693.cf

150. Vazquez-Villaseñor I, Garwood CJ, Heath PR et al (2019) Expression of p16 and p21 in the frontal association cortex of ALS/MND brains suggests neuronal cell cycle dysregulation and astrocyte senescence in early stages of the disease. Neuropathol Appl Neurobiol 46:171-185. https://doi.org/10.1111/ nan.12559

151. Parakh S, Atkin JD (2016) Protein folding alterations in amyotrophic lateral sclerosis. Brain Res 1648:633-649. https://doi.org/ 10.1016/j.brainres.2016.04.010

152. Schaffer L-N, Carter WG (2020) Do post-translational modifications influence protein aggregation in neurodegenerative diseases: a systematic review. Brain Sci 232:1-30

153. Paré B, Lehmann M, Beaudin M et al (2018) Misfolded SOD1 pathology in sporadic amyotrophic lateral sclerosis. Sci Rep. https://doi.org/10.1038/s41598-018-31773-z 
154. Scotter EL, Chen HJ, Shaw CE (2015) TDP-43 proteinopathy and ALS: insights into disease mechanisms and therapeutic targets. Neurotherapeutics 12:352-363. https://doi.org/10.1007/ s13311-015-0338-X

155. Blokhuis AM, Groen EJN, Koppers M et al (2013) Protein aggregation in amyotrophic lateral sclerosis. Acta Neuropathol 125:777-794. https://doi.org/10.1007/s00401-013-1125-6

156. Osaka M, Ito D, Suzuki N (2016) Disturbance of proteasomal and autophagic protein degradation pathways by amyotrophic lateral sclerosis-linked mutations in ubiquilin 2. Biochem Biophys Res Commun 472:324-331. https://doi.org/10.1016/j.bbrc.2016.02. 107

157. Kabashi E, Durham HD (2006) Failure of protein quality control in amyotrophic lateral sclerosis. Biochim Biophys Acta Mol Basis Dis 1762:1038-1050. https://doi.org/10.1016/j.bbadis. 2006.06.006

158. Maurel C, Dangoumau A, Marouillat S et al (2018) Causative genes in amyotrophic lateral sclerosis and protein degradation pathways: a link to neurodegeneration. Mol Neurobiol 55:64806499. https://doi.org/10.1007/s12035-017-0856-0

159. Wang IF, Guo BS, Liu YC et al (2012) Autophagy activators rescue and alleviate pathogenesis of a mouse model with proteinopathies of the TAR DNA-binding protein 43. Proc Natl Acad Sci USA 109:15024-15029. https://doi.org/10.1073/pnas. 1206362109

160. Cheng CW, Lin MJ, Shen CKJ (2015) Rapamycin alleviates pathogenesis of a new Drosophila model of ALS-TDP. J Neurogenet 29:59-68. https://doi.org/10.3109/01677063.2015.10778 32

161. Perera ND, Sheean RK, Lau CL et al (2018) Rilmenidine promotes MTOR-independent autophagy in the mutant SOD1 mouse model of amyotrophic lateral sclerosis without slowing disease progression. Autophagy 14:534-551. https://doi.org/10.1080/ 15548627.2017 .1385674

162. Foster A, Rea S (2020) The role of sequestosome 1/p62 protein in amyotrophic lateral sclerosis and frontotemporal dementia pathogenesis. Neural Regen Res 15:2186-2194. https://doi.org/ 10.4103/1673-5374.284977

163. Ma S, Attarwala IY, Xie X (2019) SQSTM1/p62: A potential target for neurodegenerative disease. ACS Chem Neurosci 10:2094-2114. https://doi.org/10.1021/acschemneuro.8b00516

164. Ramesh N, Pandey UB (2017) Autophagy dysregulation in ALS: when protein aggregates get out of hand. Front Mol Neurosci 10:1-18. https://doi.org/10.3389/fnmol.2017.00263

165. Gal J, Ström AL, Kilty R et al (2007) P62 accumulates and enhances aggregate formation in model systems of familial amyotrophic lateral sclerosis. J Biol Chem 282:11068-11077. https://doi.org/10.1074/jbc.M608787200

166. Tanji K, Zhang HX, Mori F et al (2012) P62/sequestosome 1 binds to TDP-43 in brains with frontotemporal lobar degeneration with TDP-43 inclusions. J Neurosci Res 90:2034-2042. https://doi.org/10.1002/jnr.23081

167. Rubino E, Rainero I, Chiò A et al (2012) SQSTM1 mutations in frontotemporal lobar degeneration and amyotrophic lateral sclerosis. Neurology 79:1556-1562. https://doi.org/10.1212/WNL. 0b013e31826e25df

168. Wang Y, Zhang N, Zhang L et al (2016) Autophagy regulates chromatin ubiquitination in DNA damage response through elimination of SQSTM1/p62. Mol Cell 63:34-48. https://doi.org/10. 1016/j.molcel.2016.05.027

169. Fradet-Turcotte A, Canny MD, Escribano-Díaz C et al (2013) 53BP1 is a reader of the DNA-damage-induced H2A Lys 15 ubiquitin mark. Nature 499:50-54. https://doi.org/10.1038/natur e12318
170. Brady OA, Meng P, Zheng Y et al (2011) Regulation of TDP-43 aggregation by phosphorylation andp62/SQSTM1. J Neurochem 116:248-259. https://doi.org/10.1111/j.1471-4159.2010.07098.x

171. Chen YP, Zheng ZZ, Chen XP et al (2014) SQSTM1 mutations in Han Chinese populations with sporadic amyotrophic lateral sclerosis. Neurobiol Aging 35:726.e7-726.e9. https://doi.org/10. 1016/j.neurobiolaging.2013.09.008

172. Sun Y, Curle AJ, Haider AM, Balmus G (2020) The role of DNA damage response in amyotrophic lateral sclerosis. Essays Biochem 64:847-861. https://doi.org/10.1042/EBC20200002

173. Lee YJ, Chou TF, Pittman SK et al (2017) Keap1/Cullin3 modulates p62/SQSTM1 activity via UBA domain ubiquitination. Cell Rep 19:188-202. https://doi.org/10.1016/j.celrep.2017.08.019

174. Lee H, Kim MN, Ryu KY (2017) Effect of p62/SQSTM1 polyubiquitination on its autophagic adaptor function and cellular survival under oxidative stress induced by arsenite. Biochem Biophys Res Commun 486:839-844. https://doi.org/10.1016/j. bbrc.2017.03.146

175. Goode A, Rea S, Sultana M et al (2016) ALS-FTLD associated mutations of SQSTM1 impact on Keap1-Nrf2 signalling. Mol Cell Neurosci 76:52-58. https://doi.org/10.1016/j.mcn.2016.08. 004

176. Bartolome F, Esteras N, Martin-Requero A et al (2017) Pathogenic p62/SQSTM1 mutations impair energy metabolism through limitation of mitochondrial substrates. Sci Rep 7:1-14. https://doi.org/10.1038/s41598-017-01678-4

177. Yeo BK, Yu SW (2016) Valosin-containing protein (VCP): structure, functions, and implications in neurodegenerative diseases. Animal Cells Syst (Seoul) 20:303-309. https://doi.org/10.1080/ 19768354.2016.1259181

178. Acs K, Luijsterburg MS, Ackermann L et al (2011) The AAAATPase VCP/p97 promotes 53BP1 recruitment by removing L3MBTL1 from DNA double-strand breaks. Nat Struct Mol Biol 18:1345-1350. https://doi.org/10.1038/nsmb.2188

179. Ayaki T, Ito H, Fukushima $\mathrm{H}$ et al (2014) Immunoreactivity of valosin-containing protein in sporadic amyotrophic lateral sclerosis and in a case of its novel mutant. Acta Neuropathol Commun 2:1-14. https://doi.org/10.1186/s40478-014-0172-0

180. Koppers M, van Blitterswijk MM, Vlam L et al (2012) VCP mutations in familial and sporadic amyotrophic lateral sclerosis. Neurobiol Aging 33:837.e7-837.e13. https://doi.org/10. 1016/j.neurobiolaging.2011.10.006

181. Gitcho MA, Strider J, Carter D et al (2009) VCP mutations causing frontotemporal lobar degeneration disrupt localization of TDP-43 and induce cell death. J Biol Chem 284:1238412398. https://doi.org/10.1074/jbc.M900992200

182. Schuetz AK, Kay LE (2016) A dynamic molecular basis for malfunction in disease mutants of p97/VCP. Elife 5:1-25. https://doi.org/10.7554/eLife.20143

183. van den Boom J, Wolf M, Weimann L et al (2016) VCP/p97 extracts sterically trapped $\mathrm{Ku} 70 / 80$ rings from DNA in doublestrand break repair. Mol Cell 64:189-198. https://doi.org/10. 1016/j.molcel.2016.08.037

184. Montgomery DL (1994) Astrocytes: form, functions, and roles in disease. Vet Pathol 31:145-167. https://doi.org/10.1177/ 030098589403100201

185. Liddelow SA, Barres BA (2017) Reactive astrocytes: production, function, and therapeutic potential. Immunity 46:957967. https://doi.org/10.1016/J.IMMUNI.2017.06.006

186. Schiffer D, Cordera S, Cavalla P, Migheli A (1996) Reactive astrogliosis of the spinal cord in amyotrophic lateral sclerosis. J Neurol Sci 139:27-33. https://doi.org/10.1016/0022-510X(96) 00073-1

187. Murayama S, Inoue K, Kawakami H et al (1991) A unique pattern of astrocytosis in the primary motor area in amyotrophic 
lateral sclerosis. Acta Neuropathol 82:456-461. https://doi.org/ 10.1007/BF00293379

188. Yamanaka K, Chun SJ, Boillee S et al (2008) Astrocytes as determinants of disease progression in inherited amyotrophic lateral sclerosis. Nat Neurosci 11:251-253. https://doi.org/10. 1038/nn2047

189. Nagai M, Re DB, Nagata T et al (2007) Astrocytes expressing ALS-linked mutated SOD1 release factors selectively toxic to motor neurons. Nat Neurosci 10:615-622. https://doi.org/10. 1038/nn 1876

190. Di Giorgio FP, Boulting GL, Bobrowicz S, Eggan KC (2008) Human embryonic stem cell-derived motor neurons are sensitive to the toxic effect of glial cells carrying an ALS-causing mutation. Cell Stem Cell 3:637-648. https://doi.org/10.1016/J. STEM.2008.09.017

191. Re DB, Le Verche V, Yu C et al (2014) Necroptosis drives motor neuron death in models of both sporadic and familial ALS. Neuron 81:1001-1008. https://doi.org/10.1016/J.NEURON.2014.01.011

192. Marchetto MCN, Muotri AR, Mu Y et al (2008) Non-cellautonomous effect of human SOD1G37R astrocytes on motor neurons derived from human embryonic stem cells. Cell Stem Cell 3:649-657. https://doi.org/10.1016/J.STEM.2008.10.001

193. Kia A, McAvoy K, Krishnamurthy K et al (2018) Astrocytes expressing ALS-linked mutant FUS induce motor neuron death through release of tumor necrosis factor-alpha. Glia 66:10161033. https://doi.org/10.1002/glia.23298

194. Meyer K, Ferraiuolo L, Miranda CJ et al (2014) Direct conversion of patient fibroblasts demonstrates non-cell autonomous toxicity of astrocytes to motor neurons in familial and sporadic ALS. Proc Natl Acad Sci USA 111:829-832. https://doi.org/ 10.1073/pnas.1314085111

195. Jovičić A, Gitler AD (2017) Distinct repertoires of microRNAs present in mouse astrocytes compared to astrocyte-secreted exosomes. PLoS ONE 12:e0171418. https://doi.org/10.1371/ journal.pone.0171418

196. Varcianna A, Myszczynska MA, Castelli LM et al (2019) MicroRNAs secreted through astrocyte-derived extracellular vesicles cause neuronal network degeneration in C9orf72 ALS. EBioMedicine 40:626-635. https://doi.org/10.1016/J.EBIOM.2018. 11.067

197. Basso M, Pozzi S, Tortarolo M et al (2013) Mutant copper-zinc superoxide dismutase (SOD1) induces protein secretion pathway alterations and exosome release in astrocytes: Implications for disease spreading and motor neuron pathology in amyotrophic lateral sclerosis. J Biol Chem 288:15699-15711. https://doi.org/ 10.1074/jbc.M112.425066

198. Grad LI, Yerbury JJ, Turner BJ et al (2014) Intercellular propagated misfolding of wild-type $\mathrm{Cu} / \mathrm{Zn}$ superoxide dismutase occurs via exosome-dependent and -independent mechanisms. Proc Natl Acad Sci USA 111:3620-3625. https://doi.org/10. 1073/pnas.1312245111

199. Iguchi Y, Eid L, Parent M et al (2016) Exosome secretion is a key pathway for clearance of pathological TDP-43. Brain 139:31873201. https://doi.org/10.1093/brain/aww237

200. Tripathi P, Rodriguez-Muela N, Klim JR et al (2017) Reactive astrocytes promote ALS-like degeneration and intracellular protein aggregation in human motor neurons by disrupting autophagy through TGF- $\beta 1$. Stem Cell Rep 9:667-680. https:// doi.org/10.1016/J.STEMCR.2017.06.008

201. Zhao C, Devlin A, Chouhan AK et al (2020) Mutant C9orf72 human iPSC-derived astrocytes cause non-cell autonomous motor neuron pathophysiology. Glia 68:1046-1064. https://doi. org/10.1002/glia.23761
202. Wouters MD, van Gent DC, Hoeijmakers JHJ, Pothof J (2011) MicroRNAs, the DNA damage response and cancer. Mutat Res Fundam Mol Mech Mutagen 717:54-66

203. Tominaga K, Srikantan S, Lee EK et al (2011) Competitive regulation of nucleolin expression by HuR and miR-494. Mol Cell Biol 31:4219-4231. https://doi.org/10.1128/mcb.05955-11

204. Kobayashi J, Fujimoto H, Sato J et al (2012) Nucleolin participates in DNA double-strand break-induced damage response through MDC1-dependent pathway. PLoS ONE 7:e49245. https://doi.org/10.1371/journal.pone.0049245

205. Kawamura K, Qi F, Meng Q et al (2019) Nucleolar protein nucleolin functions in replication stress-induced DNA damage responses. J Radiat Res 60:281-288. https://doi.org/10.1093/jrr/ rry114

206. Kwon I, Xiang S, Kato M et al (2014) Poly-dipeptides encoded by the C9orf72 repeats bind nucleoli, impede RNA biogenesis, and kill cells. Science 345:1139-1145. https://doi.org/10.1126/ science. 1254917

207. Lee KH, Zhang P, Kim HJ et al (2016) C9orf72 dipeptide repeats impair the assembly, dynamics, and function of membrane-less organelles. Cell 167:774-788. https://doi.org/10.1016/j.cell. 2016.10.002

208. Schneider L, Fumagalli M, Di Fagagna FDA (2012) Terminally differentiated astrocytes lack DNA damage response signaling and are radioresistant but retain DNA repair proficiency. Cell Death Differ 19:582-591. https://doi.org/10.1038/cdd.2011.129

209. Bylicky MA, Mueller GP, Day RM (2019) Radiation resistance of normal human astrocytes: the role of non-homologous end joining DNA repair activity. J Radiat Res 60:37-50. https://doi. org/10.1093/jrr/rry084

210. Swain U, Subba Rao K (2011) Study of DNA damage via the comet assay and base excision repair activities in rat brain neurons and astrocytes during aging. Mech Ageing Dev 132:374381. https://doi.org/10.1016/j.mad.2011.04.012

211. Yamamoto A, Nakamura Y, Kobayashi N et al (2007) Neurons and astrocytes exhibit lower activities of global genome nucleotide excision repair than do fibroblasts. DNA Repair (Amst) 6:649-657. https://doi.org/10.1016/j.dnarep.2006.12.006

212. Hollensworth SB, Shen CC, Sim JE et al (2000) Glial cell typespecific responses to menadione-induced oxidative stress. Free Radic Biol Med 28:1161-1174. https://doi.org/10.1016/S08915849(00)00214-8

213. LeDoux SP, Williams BA, Hollensworth BS et al (1996) Glial cell-specific differences in repair of O6-methylguanine. Cancer Res 56:5615-5619

214. Harlan BA, Pehar M, Killoy KM, Vargas MR (2019) Enhanced SIRT6 activity abrogates the neurotoxic phenotype of astrocytes expressing ALS-linked mutant SOD1. FASEB J 33:7084-7091. https://doi.org/10.1096/fj.201802752R

215. Duval K, Grover H, Han LH et al (2017) Modeling physiological events in 2D vs. 3D cell culture. Physiology 32:266-277

216. Wu W, Hill SE, Nathan WJ et al (2021) Neuronal enhancers are hotspots for DNA single-strand break repair. Nature. https://doi. org/10.1038/s41586-021-03468-5

217. Pehar M, Harlan BA, Killoy KM, Vargas MR (2018) Role and therapeutic potential of astrocytes in amyotrophic lateral sclerosis. Curr Pharm Des 23:5010-5021. https://doi.org/10.2174/ 1381612823666170622095802

Publisher's Note Springer Nature remains neutral with regard to jurisdictional claims in published maps and institutional affiliations. 